\title{
A rapid sedimentary response to the Paleocene-Eocene Thermal Maximum hydrological change: new data from alluvial units of the Tremp-Graus Basin(Spanish Pyrenees)
}

\author{
Victoriano Pujalte $^{\mathrm{a}}$, Birger Schmitz ${ }^{\mathrm{b}}$, Aitor Payros ${ }^{\mathrm{a}}$ \\ ${ }^{a}$ Department of Geology, Faculty of Science and Technology, University of the Basque \\ Country UPV/EHU, Bilbao, Spain (Emails: victoriano.pujalte@ehu.eus; \\ a.payros@ehu.eus) \\ ${ }^{\mathrm{b}}$ Division of Nuclear Physics. Department of Physics, University of Lund, Lund, \\ Sweden (Email: birger.schmitz@nuclear.lu.se).
}

This is a non-peer reviewed preprint submitted to EarthArXiv.

The original manuscript was submitted to Palaeogeography, Palaeoclimatology Palaeoecology on 11 May 2021for peer review, yet no reviews were received five months after submission. 


\section{Palaeogeography, Palaeoclimatology, Palaeoecology}

A rapid sedimentary response to the Paleocene-Eocene Thermal Maximum hydrological change: new data from alluvial units of the Tremp-Graus Basin (Spanish Pyrenees)

--Manuscript Draft--

Manuscript Number:

Article Type:

Keywords:

Corresponding Author:

First Author:

Order of Authors:

Manuscript Region of Origin:

Abstract:
Research Paper

Alluvial units; organic carbon isotopes; CIE onset; PETM; Pyrenees

Victoriano Pujalte, Dr

University of the Basque Country: Universidad del Pais Vasco

Leioa, Bizkaia SPAIN

Victoriano Pujalte, Emeritus Professor

Victoriano Pujalte, Emeritus Professor

Birger Schmitz, Professor

Aitor Payros, Lecturer

Europe

Abstract

A massive emission of light carbon about $56 \mathrm{Ma}$ ago, recorded in marine and terrestrial sediments by a negative carbon isotope excursion (CIE), caused a short-lived ( 170 kyr) global warming event known as the Paleocene-Eocene Thermal Maximum (PETM). The core of this event is represented in the south Pyrenean Tremp-Graus Basin by two successive alluvial units, the Claret Conglomerate (CC) and the Yellowish Soils, which represent laterally juxtaposed depositional environments. It is generally agreed that these units record a dramatic increase in seasonal rain and an increased intra-annual humidity gradient during the PETM, but the timing of the sedimentary response to the hydrological change is a matter of debate. Some authors maintain that the $\mathrm{CC}$ was developed during the early, most intense phase of the carbon emission, others that its formation lagged by $16.5 \pm 7.5 \mathrm{kyr}$ behind the onset of the PETM. The latter claim was mainly based on the assumption that in two sections of this basin, Claret and Tendrui, the onset of the CIE occurs 3 and $8 \mathrm{~m}$ below the base of the CC, respectively. Here we show that in the zone between these two sections the $\mathrm{CC}$ is missing and the Yellowish Soil unit rests directly and conformably on the underlying deposits. New d13Corg data from this zone provide sound evidence that the onset of the CIE is situated just $\sim 1 \mathrm{~m}$ below the Yellowish Soils. The CC erosional base cuts down deeper than this figure, rendering it highly unlikely the preservation of the CIE onset below it. A tentative estimate based on sedimentation rates indicates that $\sim 3.8$ kyr, or less, may have elapsed from the onset of the CIE to the arrival of PETM alluvium into the Claret-Tendrui study area, about a third of the lowest estimate of previous authors. Since the study area was situated about $15 \mathrm{~km}$ from the source area, our new estimate supports a rapid response of the sedimentary system to the hydrological change at the onset of the PETM. 


\section{Highlights - Pujalte et al}

The PETM hydrological change is recorded in the Pyrenees by two alluvial units

Between the PETM onset and the alluvial accumulation a lag of $\sim 3.8 \mathrm{kyr}$ is estimated

The new data entail a rapid sedimentary response to the PETM hydrological change 
1 A rapid sedimentary response to the Paleocene-Eocene Thermal Maximum

2 hydrological change: new data from alluvial units of the Tremp-Graus Basin

3 (Spanish Pyrenees)

$4 \quad$ Victoriano Pujalte ${ }^{\mathrm{a}}$, Birger Schmitz ${ }^{\mathrm{b}}$, Aitor Payros $^{\mathrm{a}}$

$5 \quad{ }^{a}$ Department of Geology, Faculty of Science and Technology, University of the Basque

6 Country UPV/EHU, Bilbao, Spain

$7 \quad$ b Division of Nuclear Physics. Department of Physics, University of Lund, Lund, Sweden

8 *Corresponding author. E-mail address: victoriano.pujalte@ehu.eus.

9 Abstract

A massive emission of light carbon about $56 \mathrm{Ma}$ ago, recorded in marine and terrestrial sediments by a negative carbon isotope excursion (CIE), caused a short-lived ( 170 kyr) global warming event known as the Paleocene-Eocene Thermal Maximum (PETM). The core of this event is represented in the south Pyrenean Tremp-Graus Basin by two successive alluvial units, the Claret Conglomerate (CC) and the Yellowish Soils, which represent laterally juxtaposed depositional environments. It is generally agreed that these units record a dramatic increase in seasonal rain and an increased intra-annual humidity gradient during the PETM, but the timing of the sedimentary response to the hydrological change is a matter of debate. Some authors maintain that the CC was developed during the early, most intense phase of the carbon emission, others that its formation lagged by $16.5 \pm 7.5 \mathrm{kyr}$ behind the onset of the PETM. The latter claim was mainly based on the assumption that in two sections of this basin, Claret and Tendrui, the onset of the CIE occurs 3 and $8 \mathrm{~m}$ below the base of the $\mathrm{CC}$, respectively. Here we show that in the zone between these two sections the $\mathrm{CC}$ is missing and the Yellowish Soil unit rests directly and conformably on the underlying deposits. New $\delta^{13} \mathrm{C}_{\text {org }}$ data from this zone provide sound evidence that the onset of the CIE is situated just $\sim 1 \mathrm{~m}$ below the Yellowish Soils. The CC erosional base cuts down deeper than this figure, rendering it highly unlikely the preservation of the CIE onset below it. A tentative 
estimate based on sedimentation rates indicates that $\sim 3.8 \mathrm{kyr}$, or less, may have elapsed from the onset of the CIE to the arrival of PETM alluvium into the Claret-Tendrui study area, about a third of the lowest estimate of previous authors. Since the study area was situated about $15 \mathrm{~km}$ from the source area, our new estimate supports a rapid response of the sedimentary system to the hydrological change at the onset of the PETM.

Key words: Alluvial units; organic carbon isotopes; CIE onset; PETM; Pyrenees

\section{Introduction}

The long-term environmental impact of the ongoing global warming is a matter of great concern and debate. One of its predicted effects is an alteration of the hydrological cycle, because a warmer atmosphere can hold more moisture (Held and Soden, 2006). However, the timing of the sedimentary response to such environmental changes remains uncertain. One way to predict these effects is modelling (Deser et al., 2020). For example, the modelling of river behaviour by Simpson and Castelltort (2012, p.1134) showed that variations in water discharge likely transmit, and can even amplify, sedimentary signals to downstream archives. Examples from modern alluvial systems also indicate that the sedimentary reaction to large rainfall events can be nearly instantaneous. For instance, an exceptional rainstorm (locally $>600 \mathrm{l} / \mathrm{m}^{2}$ ) in the semiarid southeast of the Iberian Peninsula caused a catastrophic flood on October 18, 1973 (Capel Molina, 1974), after which a small fan delta in the coastal village of La Rábita experienced a seaward progradation of up to $270 \mathrm{~m}$ (Fig. 1).

An alternative way to learn about the sedimentary response to global warming and concomitant changes of the hydrological cycle is the study of past analogues, such as the Paleocene-Eocene Thermal Maximum (PETM), a short-lived ( 170 kyr) global warming event that increased Earth's temperature by $\sim 5-8^{\circ} \mathrm{C}$ about $56 \mathrm{Ma}$ ago. It was 
caused by a massive injection of light carbon into the ocean-atmosphere reservoirs, which was recorded in marine and terrestrial deposits by a prominent negative carbon isotope excursion (CIE) (Koch et al., 1992; Sluijs et al. 2007; Zachos et al. 2008; McInerney and Wing 2011). Hydrological changes induced by the PETM have been reported in numerous studies. For instance, this event caused abrupt changes in alluvial architecture in the Piceance Creek Basin, Colorado, (Foreman et al., 2012; Foreman, 2014) and the Uinta Basin, Utah (Plink-Björklund et al., 2014), as well as an alteration of the stacking pattern and type of paleosols in the terrestrial Big Horn Basin, Wyoming (Kraus et al., 2013, 2015). Increased influx of terrestrial clays attributed to intensified rainfall and runoff have also been reported from widely separated continental margins (Gibson et al., 2000; Schmitz et al., 2001; John et al., 2008; Handley et al., 2012; Slotnick et al., 2012), while a massive input of both fine- and coarse-grained siliciclastics temporarily halted a long-lasting carbonate deposition in shallow marine areas of the Pyrenees (Pujalte et al., 2016; Pujalte and Schmitz, 2019) and the Xigaze forearc basin of the Tibet (Jiang et al., 2021).

The Claret Conglomerate (CC) of the Tremp-Graus Basin (southern Pyrenees), the focus of this study, is another prominent and amply referenced case (Schmitz and Pujalte, 2003, 2007; Armitage, et al., 2011, 2013; Foreman et al., 2012; Minelli et al., 2013; Foreman, 2014; Pancost, 2017; Colombera et al., 2017; Allen, 2017; Carmichael et al., 2017, 2018). However, the time relationship between the PETM hydrological change and the sedimentary response recorded by the $\mathrm{CC}$ has created some discussion. Schmitz and Pujalte (2007), for instance, suggested that the CC was accumulated during the first $10 \mathrm{kyr}$, or less, of the PETM, which implies a rapid sedimentary response. Instead, Domingo et al. (2009), Manners et al. (2013) and Duller et al. (2019) (henceforward referred to collectively as DMD 09-19), mainly based on the study of 
$\delta^{13} \mathrm{C}_{\text {org }}$ of two sections (Claret and Tendrui, here named Claret road and $\mathrm{T}_{\mathrm{DMD}}$ ), concluded that the onset of the thermal event predated the CC by $16.5 \pm 7.5 \mathrm{kyr}$ and postulated a delayed response of the sedimentary system to the PETM hydrological change.

A first purpose of this paper is to address this discrepancy. To this end, a detailed field study has been carried out in an area situated to the west of Tremp (study area in Supplementary Fig. 1A). Eight reference Paleocene-Eocene boundary sections were studied and sampled, including the controversial Claret and $\mathrm{T}_{\mathrm{DMD}}$ sections, and a detailed field mapping of their surroundings was undertaken with the aim of gaining a wider perspective. As a result, the internal architecture of the $\mathrm{CC}$ in this area has been documented for the first time, shedding new light on the development of the unit. In addition, an attempt is made to estimate the rate of the sedimentary change induced by the PETM hydrological change, as recorded by the arrival of PETM alluvial clastics to the study area.

\section{Geological setting, stratigraphy and prior information}

In early Paleogene times the Tremp-Graus Basin was situated in the southeastern part of the Pyrenean marine gulf, an E-W elongated embayment opening westwards into the Bay of Biscay at $\sim 35^{\circ} \mathrm{N}$ palaeolatitude (Fig. 2A; Baceta et al., 2011; Pujalte et al., 2016). The eastern part of the basin was mostly infilled with terrestrial deposits (Fig. 2B), informally named "Garumnian" (Rosell et al., 2001) and formally Tremp Group (Cuevas, 1992; Pujalte and Schmitz, 2005; Pujalte et al., 2014). This Group is sandwiched between shallow marine deposits, the Maastrichtian Aren Sandstone Formation below and the informal "Alveolina limestone" unit above (Ilerdian = lower 
100 Ypresian), and interfingers to the west with lacustrine and shallow marine carbonates

101 (Pujalte et al., 2014).

102 In the Tremp-Graus Basin the PETM interval was first identified by Schmitz and Pujalte 103 (2003) in the Esplugafreda section, mainly based on analyses of $\delta^{13} \mathrm{C}$ of soil carbonate 104 nodules (Supplementary Figs. 2A, B). Ten years later Manners et al (2013) studied the 105 isotopic composition of dispersed organic carbon of bulk samples $\left(\delta^{13} \mathrm{C}_{\mathrm{org}}\right)$ across the 106 Paleocene-Eocene boundary (P-E) interval of this section, placing the PETM in the 107 same position (Supplementary Fig. 2C).

In the present study area, situated about $10 \mathrm{~km}$ to the south of Esplugafreda and just west of the city of Tremp (Fig. 2B, Supplementary Fig. 1), the P-E boundary interval comprises four of the five lithostratigraphic units recognized at Esplugafreda (Fig. 2C), their characteristics being summarized below from older to younger.

The Esplugafreda Formation (Thanetian, $\sim 350 \mathrm{~m}$ thick at Claret) is mostly made up of overbank red and variegated silty mudstones with irregular intercalations of channelized calcarenites and calcareous conglomerates. The red mudstones include soil carbonate nodules, Microcodium (submillimeter-sized monocrystalline prisms of calcite originated on roots of terrestrial plants) and a whole range of gypsum facies, from rosettes and root-like molds to massive alabastrine accumulations up to $4 \mathrm{~m}$ thick, interpreted as deposits of ephemeral saline lakes (García-Veigas, 1988), all of which provide evidence of semiarid to arid conditions.

The incised valley fill occurs within an erosional depression ca. $1.5 \mathrm{~km}$ wide and up to 30 m deep excavated on the Esplugafreda Formation during a lowstand period predating the PETM (Fig. 2D; Pujalte et al., 2014). The lithological composition of this infill is markedly different to that of the Esplugrafreda Formation. It comprises coarse-grained 
imbricated conglomerates in its lower part that record westward flowing currents (Figs.

3A, B). The bulk of the unit, however, consists of alternating light gray calcarenites and marlstones devoid of carbonate nodules but rich in coalified remains, including occasional amber fragments, and even a small tree trunk buried in living position (Figs. 3C, D). The grey colours and abundant preservation of organic material are indicative of reducing conditions, probably in an aquatic/riparian setting. A minor but significant part of this unit consists of red mudstones with scattered soil carbonate nodules indicative of well-oxygenated conditions (Fig. 4A), their location attesting to the final infilling of the incised valley (Fig. 2D). Interestingly, the uppermost $30 \mathrm{~cm}$ of the red mudstones are intensely altered (Fig. 4B). The altered zone contains abundant carbonate nodules that can be easily crushed and can hence be considered (sub)recent, an indication that the alteration was produced by hard waters percolating through the overlying CC.

Alteration of sediments situated just below the $\mathrm{CC}$ has also been observed in other sections (e.g. Supplementary Fig. 3A).

The $\mathrm{CC}$ is an extensive sheet-like unit up to $4 \mathrm{~m}$ thick, of clast-supported calcareous conglomerates, pebbly calcarenites and minor mudstones, further described below. The Yellowish soil unit is up to $20 \mathrm{~m}$ thick in the study area and mainly consists of finegrained mudstones of a light yellow colour in weathered exposures, with intercalated calcarenite channels 1-5 $\mathrm{m}$ thick but modest lateral extent $(5-20 \mathrm{~m})$. The mudstones contain abundant small-sized $(\leq 1 \mathrm{~cm})$ soil carbonate nodules evenly distributed throughout the unit, but neither Microcodium nor gypsum have been observed. In proximal areas of the basin (e.g., Esplugafreda, Supplementary Fig. 1A) the Yellowish Soils always overlie the CC. However, according to the Walther's Law of Facies, both units represent frontally juxtaposed depositional environments, which imply that the CC must grade distally into the Yellowish Soils. 
The uppermost gypsum-rich unit is usually represented by red mudstones crisscrossed by gypsum veins and rosettes and locally by a 4 m thick package of massive alabastrine gypsum. In some section this massive gypsum package is overlain by fresh-water

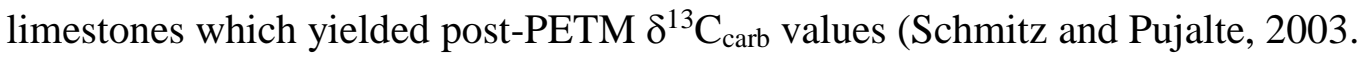

153 Supplementary Fig. 3B).

154 Previous isotope records from soil carbonate nodules $\left(\delta^{13} \mathrm{C}_{\text {carb }}\right.$; Schmitz and Pujalte, 2003, 2007; Pujalte et al., 2014; Minelli et al., 2013) and from bulk dispersed organic matter in the Esplugafreda section $\left(\delta^{13} \mathrm{C}_{\text {org }}\right.$; Manners et al., 2013, Supplementary Fig. 2C) indicate that the Esplugafreda Formation and the incised valley fill deposits predate the PETM, the CC and the Yellowish Soils encompass the core of the thermal event, while the recovery to pre-event background conditions is recorded in the gypsum-rich unit. However, the onset of the CIE in the study area is controversial. Schmitz and Pujalte (2003), Pujalte and Schmitz (2005) and Pujalte et al. (2009) placed it at the base of the CC, whereas DMD (09-19) maintain that it occurs below the CC, at about $-3 \mathrm{~m}$ in the Claret section (here called Claret road; Fig. $2 \mathrm{C}$ ) and $-8 \mathrm{~m}$ in the $\mathrm{T}_{\mathrm{DMD}}$ section.

\section{Material and methods}

This study is mainly based on field observations, aided with satellite images of Google Earth and the Institut Cartogràfic i Geològic de Catalunya. The P-E boundary interval succession of the study area was re-mapped and the best outcrops photographed with a digital camera to facilitate the analysis of their facies and depositional architecture. Palaeocurrents were obtained from cross-bedding and the orientation of large scale dunes. 
171 Previously published $\delta^{13} \mathrm{C}_{\text {carb }}$ isotopic data from Schmitz and Pujalte (2003), Pujalte et

172

173

al. (2009) (Supplementary Fig. 3B) and $\delta^{13} C_{\text {org }}$ isotopic data from DMD (09-19) were reassessed. In addition, nine sections were studied in detail, in eight of which 100 new samples were collected to analyze the isotopic composition of dispersed organic carbon. To this end, the hardest pieces of the samples (i.e. the best preserved) were cleaned with distilled water to eliminate surface dust, dried at $30^{\circ}$ in an oven for 24 hours and finely ground on an agate mortar. The resulting powdered samples were analyzed for $\delta^{13} \mathrm{C}$ of bulk dispersed organic matter at the Servizos de Apoio á Investigación (SAI) of the University of A Coruña, Spain. Powdered samples were weighed $(400 \mu \mathrm{g})$ into $12 \mathrm{~mL}$ exetainers, sealed, and then flushed with helium to displace and replace the air contained above the samples. After the flushing process was complete, about $100 \mu \mathrm{L}$ of ortho-phosphoric acid were added to each sample. The samples were kept at $26^{\circ} \mathrm{C}$ and left to react with the acid for $24 \mathrm{~h}$. The resulting headspace $\mathrm{CO}_{2}$ was passed through a Poraplot Q fused silica capillary column $(25 \mathrm{~m}, 0.32 \mathrm{~mm}$, Varian $)$ maintained at $70^{\circ} \mathrm{C}$, and finally through a capillary was introduced into the ionization chamber of a mass spectrometer. The carbon isotope ratio of $\mathrm{CO}_{2}$ gas extracted from solid samples was measured using a ThermoFinnigan MAT253 isotope ratio mass spectrometer interfaced with a ThermoFinnigan Gas Bench II device and a GC-PAL autosampler (CTC Analytics). The system was calibrated with NBS19, NBS18 and LSVEC standards, supplied by IAEA, Vienna, Austria. The results are reported with the conventional delta notation with respect to VPDB (Vienna Pee Dee Belemnite).

\section{Results}

The $\mathrm{CC}$ is discontinuous in the study area, probably due to its relatively distal location ( $\sim 15 \mathrm{~km}$ to the south of the source area, Supplementary Fig. 1). When the CC is absent, 
the Esplugafreda Formation is directly overlain by the Yellowish Soils (Figs. 2C, D). Thus, the P-E boundary interval successions present some significant differences in the Claret and Tendrui sectors, as well as in the intervening St Adria valley. These three zones are described separately below.

\subsection{The P-E boundary interval in the Claret sector}

The CC stretches for about $1.5 \mathrm{~km}$ in a N-S transect of the Claret sector, from the Palau creek in the south to the Ricos creek in the north, almost everywhere overlying the incised valley deposits (Figs. 2C, D). Due to its weathering resistant nature, the CC has created a cuesta landform, the top surface of which is widely exposed on the westdipping gentle slope. This surface is generally sharp and nearly flat and is crisscrossed by a conspicuous conjugate set of joints, clearly noticeable in satellite images (Supplementary Figs. 4A, B). In turn, the CC has created a small cliff in the cuesta steep slope (Supplementary Fig. 4D).

Four sections have been studied in this sector, three of which were sampled (Fig. 2D). The Claret north, Claret hamlet and Palau sections are illustrated in Figs. 5 and 6 and briefly described below. The fourth one, the Claret road section, is dealt with in more detail in the next point, both to clarify the position of the base of the CIE and because it provides important clues about the internal architecture and development of the CC.

\subsubsection{The Claret north, Claret hamlet and Palau sections}

In the Claret north section, which is oriented nearly perpendicular to palaeocurrents (Fig. 5A), the CC is about $4 \mathrm{~m}$ thick and it is made up of stacked tabular packages of clast-supported conglomerates and lesser amounts of pebbly sandstones delimited by erosional surfaces (Fig. 5B). The lower boundary of the CC is sharp and slightly erosional, cutting $\sim 60 \mathrm{~cm}$ into well exposed grey calcarenites and marlstones of the 
incised valley fill. The Palau creek section offers a NE-SW oriented vertical exposure, near parallel to palaeocurrents, in which large-scale unidirectional cross-bedding can be observed (Fig. 5C). Taken together, these two sections permit a 3D reconstruction of the internal architecture of the unit, providing a first indication of its south-westwards progradation.

224

The incised valley fill deposits situated just below the CC were analyzed for organic carbon isotopes in the Claret north and Claret hamlet sections (Fig. 6). The former exposes $\sim 2 \mathrm{~m}$ of grey calcarenites and marls, from which 15 samples were collected at close-spaced intervals. The lower 10 samples provided a vertical stable trend, with $\delta^{13} \mathrm{C}_{\text {org }}$ values ranging between -22 and $-23.6 \%$ (in black in Fig. 6A). Four out of the upper five samples, collected in the $20 \mathrm{~cm}$ interval situated just below the $\mathrm{CC}$, also yielded low values (-22.7 to $-24.2 \%$ ), the remaining one being somewhat more negative (-25.2\% ; red in Fig. 6A).

In the Claret hamlet section the $\mathrm{CC}$ is underlain by about $5 \mathrm{~m}$ of red calcareous mudstones with scattered soil carbonate nodules. $\delta^{13} \mathrm{C}_{\text {org }}$ values from four bulk samples of the red mudstones gave values between -24.4 and $-23.9 \%$ (Fig. 6B). In this same section Pujalte et al. (2009) reported the $\delta^{13} \mathrm{C}_{\text {carb }}$ values of three nodules samples, respectively $-7.3,-7.6$ and $-7.7 \%$ (Supplementary Fig. 3B).

\subsubsection{The Claret road section}

The P-E boundary interval of the Claret road section is exposed in the trench of the road C-1311 from Tremp to the Montllobat Pass, near km 22. Due to its easy access it is the most studied and referenced section of the Claret sector (Pujalte and Schmitz, 2005; Pujalte et al., 2009; Domingo et al., 2009; Minelli et al., 2013; Manners et al., 2013; 
243 problem with this section is that the boundary between the incised valley deposits and

244 the CC is not exposed, as it is covered up by a dense thicket of bushes and trees (Fig.

245 7A, Supplementary Fig. 5A). To overcome the problem, the scattered outcrops of the

246 CC within the thicket were mapped in this study and connected with the road exposure.

247 The uppermost incised valley deposit exposed in the road is a $\sim 1 \mathrm{~m}$ thick calcarenite

248 bed ("reference calcarenite"), the CC base being situated about $2 \mathrm{~m}$ above it (Figs. 7B,

249 C). Between the reference calcarenite and the $\mathrm{CC}$ base vegetation and a thick recent soil

250 preclude digging out fresh samples.

251 The CC is well outcropped in the road trench to the west of the thicket, but the

252 underlying incised valley deposits are not exposed therein (Fig. 8). The CC is mainly composed of calcareous conglomerates and pebbly calcarenites, but it also contains sizable intercalations of marly clays. Cross-stratifications in some of the conglomeratic beds consistently indicate west-directed palaeocurrents (Fig. 8), which demonstrates that the road trench provides a near dip oriented view of the CC. A large scale lowangle cross-stratification of the CC coarse beds is also evident, which denotes a westward progradation of the unit (Fig. 8A).

Pinpointing the top of the $\mathrm{CC}$ in the road trench itself is difficult because the unit is there directly overlain by one of the younger calcarenite channels intercalated in the Yellowish Soils. However, the near flat upper surface of the CC is widely exposed just north of the road, being readily recognizable by its tell-tale conjugate set of joints (Fig. 7A, Supplementary Figs. 5B, C). Tracing this surface to the road trench demonstrates that the alleged CC base in DMD (09-19) is actually situated only about $1 \mathrm{~m}$ below the top of the unit (Fig. 8A, Supplementary 5D). This circumstance inescapably demands that the samples collected by DMD (09-19) 3 m below their CC base, which provided 
PETM values, must have been taken from marly clays intercalated within the $\mathrm{CC}$, as indicated by Pujalte and Schmitz (2014).

269 In this study six samples were collected for organic carbon isotope analysis, three from

270 the incised valley deposits and three from the marly clays of the CC (Figs. 7C, 8A).

271 Those of the incised valley fill provide $\delta^{13} \mathrm{C}_{\text {org }}$ values between -23.1 and $-23.6 \%$,

272 whereas those of the CC range between -25.3 and $-26.1 \%$, averaging out at $-25.6 \%$.

\subsection{The P-E boundary interval in St Adria valley}

The St Adria creek has excavated a narrow valley that in its lower reach is about $80 \mathrm{~m}$ deep and exposes the entire P-E interval in both of its steep margins (Fig. 2C). The CC is discontinuous and only occurs on the southern one (Fig. 2C). When the $\mathrm{CC}$ is absent the uppermost part of the Esplugafreda Formation consists of red silty marls with abundant $\mathrm{CaCO}_{3}$ soil nodules capped by a $30-50 \mathrm{~cm}$ thick interval of clays with a conspicuous purple colour (Fig. 9A). This "purple cap", which is devoid of carbonate nodules but contains numerous small diameter $(\leq 1 \mathrm{~mm})$ ferruginous nodules (Fig 9B), was found in every accessible outcrop of the St Adria valley in which the CC is absent, a proof that it is not a localized feature. The Yellowish Soils overlie directly and conformably this purple cap.

Two separate CC packages are observable on the southern margin of the valley, both of them almost entirely encased within the Esplugafreda Formation (Figs. 10A, B). The one situated to the WNW is about $150 \mathrm{~m}$ wide and $2 \mathrm{~m}$ thick (Fig. 10B). In the zone between both CC packages a section, coded Ad-S, was sampled at close-spaced intervals across the Esplugafreda/Yellowish Soils transition (Figs. 10C, D). The five samples situated between -230 and $-140 \mathrm{~cm}$ below the boundary gave a narrow range of

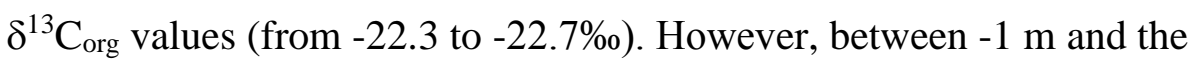


291 Esplugafreda/Yellowish Soils boundary, $\delta^{13} \mathrm{C}_{\text {org }}$ values became gradually more

292 negative, first slowly and then rapidly, peaking at a minimum of $-28.5 \%$ in the purple

293 cap (Fig. 10C). Values of five samples analyzed from the overlying Yellowish Soils

294 remain quite negative, ranging between -24.9 and $-26.6 \%$.

295 The Esplugafreda/Yellowish soil boundary is also well exposed to the west of the

296 WNW termination of the CC, except where a calcarenite channel intercalated in the

297 Yellowish locally impinges on the Esplugafreda Formation (Figs 10E). Below both the

298 CC and the calcarenite channel, the purple cap has been eroded away.

299 On the northern margin of the St Adria valley the Yellowish Soils unit generally rests

300 directly on the Esplugafreda Formation, as the $\mathrm{CC}$ is there absent. Two sections from

301 this margin were analyzed, coded $\mathrm{Ad}-\mathrm{N}_{1}$ and $\mathrm{Ad}-\mathrm{N}_{2}$, respectively (Fig. 11A). A reduced

302 purple cap is discernible in the former (Figs. 11B). In the upper $2.75 \mathrm{~m}$ of the

303 Esplugafreda Formation, which have a similar composition to that in the AD-S section,

304 including abundant carbonate nodules (Fig. 11C), seventeen mudstone samples were

305 collected for organic carbon isotope analysis. Values of the lower thirteen of these

306

samples vary between -22.3 and $-23.4 \%$, averaging out at $-22.7 \%$, but in the

307

uppermost $0.5 \mathrm{~m}$ of the Esplugafreda Formation values gradually decrease, peaking at -

308

$25.8 \%$ in the purple cap (Fig. 11B).

309

310

311

312

313

314

The Ad- $\mathrm{N}_{2}$ section encompasses the uppermost $30 \mathrm{~m}$ of the Esplugafreda Formation, which are composed of alternating grey gypsiferous marls and red and variegated mudstones rich in carbonate nodules. The top of the Esplugafreda Formation is abruptly truncated by a $2 \mathrm{~m}$ thick calcarenite channel, in turn overlain by the Yellowish Soils (Figs 11A, D). The $\delta^{13} \mathrm{C}_{\text {org }}$ values throughout the Esplugafreda Formation are quite stable, varying between -23 and $-24 \%$ and averaging out at $23.5 \%$. A more negative 
value $(-27 \%)$ is recorded in the calcarenite channel, the negative values $(-26 \%)$ persisting within the overlying Yellowish Soils (Fig. 11D).

Schmitz and Pujalte (2003) sampled at low resolution another section of the St Adria northern margin situated about $200 \mathrm{~m}$ to the WNW of the Ad- $\mathrm{N}_{1}$ section (S\&P 2003 in Fig. 2D). The exposed part of the Esplugafreda Formation successively comprised grey marls with gypsum, red mudstones with carbonate nodules and the purple cap. Only one nodule sample was collected from the red marls, which produced a $\delta^{13} \mathrm{C}_{\text {carb }}$ value of 8.6\%o, whereas values of seven nodule samples from the Yellowish Soils varied between -12 to $-14 \%$ (Supplementary Fig. 3B).

\subsection{The P-E boundary interval in the Tendrui sector}

The CC is about $1-3 \mathrm{~m}$ thick and stretches for about $200 \mathrm{~m}$ in S-N direction in the Tendrui sector, where it rests on the Esplugafreda Formation (Fig 2C). It is overgrown with trees that prevent a proper assessment of its internal geometry. Neither can the nature of the sediments overlying the unit be established, as a farmland exists just above it (Fig. 11A).

Field observations indicate that in the Tendrui sector the $\mathrm{CC}$ is also encased within the Esplugafreda Formation. Visually this can to be observed in the southern termination of the $\mathrm{CC}$, but the encasement depth cannot be verified because of the farmland (Fig. 11A). In the northern part of the CC outcrop, however, it has been confirmed that the top of the $\mathrm{CC}$ is situated about $1 \mathrm{~m}$ below the base of the Esplugafreda Formation/Yellowish soil boundary.

Two sections located close to each other have been studied in the northern part of the Tendrui sector, the $\mathrm{T}_{\mathrm{DMD}}$ described by DMD (09-19) and one situated in the trench of a 
dirt tract about $40 \mathrm{~m}$ to the north, coded $\mathrm{T}_{\mathrm{dt}}\left(\right.$ Fig. 12A). The part of the $\mathrm{T}_{\mathrm{DMD}}$ section revisited in this study is situated in a small vegetated ravine (Figs. 12A, B; cf., small

340 photo in fig. 3 of Domingo et al., 2009). It comprises a $20 \mathrm{~m}$ thick segment of the

341 Esplugafreda Formation situated immediately below the CC, the lowermost part of

342 which is formed by red calcareous mudstones with carbonate nodules, the remainder by

343 brownish silty marls devoid of nodules and gypsum (Fig. 12B, C). DMD (09-19) analyzed about 20 samples from this interval, their values being plotted in Fig. 12C

345 (small diamonds, yellow in the online version). Values of five samples collected for this study (large diamonds, red in the online version, Fig. 12C) are roughly similar to those of DMD (09-19). While collecting them it was noticed that the marls become increasingly softer and discoloured up to the CC.

The nearby $\mathrm{T}_{\mathrm{dt}}$ section (Fig. 12A) comprised the $8 \mathrm{~m}$ thick interval of the Esplugafreda Formation situated just below the CC. Today this section is vegetated only in its upper part, but the excavation of the dirt track trench unearthed numerous subvertical large roots coming down throughout the section from the trees above (Fig. 12D). The section is largely covered by loose clays, but well-indurate grey-brownish silty marls are exposed along several small vertical rills coming down through most of the section, from which six samples were collected (Fig. 12D). The lower five samples were well indurated and gave $\delta^{13} \mathrm{C}_{\text {org }}$ values ranging from $-24.1 \%$ to $-24.8 \%$, averaging out at 24.4\% (Fig. 12E). The uppermost marl sample, collected in the upper vegetated part of

358 the section, was soft and contained numerous traces of recent roots, yielding a $\delta^{13} \mathrm{C}_{\text {org }}$ 359 value of $-25.2 \%$.

\section{Discussion}


The predominant coarse-grained components of the $\mathrm{CC}$ must have been transported by powerful currents, a fact that explains both the erosional base of the unit

364 (Supplementary Fig. 3A) and its encasement in the Esplugafreda Formation (Figs. 2D, 10A, B). Palaeocurrents from cross-bedding and large-scale dunes demonstrate that these currents preferentially flowed to the WSW (Fig. 5A), similar to those indicated by the clast imbrications in the basal conglomerates of the incised valley. This circumstance and the areal concurrence of the incised valley and the CC outcrops suggest that the latter unit was mainly accumulated in a residual depression of the former, which probably explains the lens-like CC shape in the Claret sector (Fig. 2D). Instead, where the $\mathrm{CC}$ overlies the Esplugafreda Formation it exhibits a near tabular 372 shape (e.g., Fig. 10B).

The most significant internal architectural features of the $\mathrm{CC}$ are observed in the Claret road section. The slope of the low-angle inclined conglomeratic strata coincides with the direction indicated by the palaeocurrents (Fig. 8A). These strata, therefore, must record a forward progradation of the CC during episodes of strong currents. Conversely, silty clays intercalated between the conglomerate strata must have been accumulated in quieter conditions, from which it seems logical to conclude that the progradation of the $\mathrm{CC}$ was intermittent, with alternating periods of activity and stillness.

\subsection{Onset of the CIE in the study area}

Interpretation of $\delta^{13} \mathrm{C}_{\text {org }}$ results obtained from bulk rocks must be treated with caution, because they may reflect variations in the proportion of autochthonous and allochthonous organic components and/or different degrees of diagenetic degradation. In marine deposits the reliability of $\delta^{13} \mathrm{C}_{\text {org }}$ curves can be validated (or disproved) through a comparison with other indicators, mainly biostratigraphic data (e.g. Storme et 
al., 2012). Such a procedure, however, is seldom applicable in terrestrial deposits, which are either barren or poorly fossiliferous, as it is the case of the successions here considered. One possible way to circumvent these problems is to analyze highmolecular weight n-alkanes (C25 to $\mathrm{C} 33$ ), which have a higher resistance to isotopic exchange (Baczynski et al., 2016). However, even this procedure does not always guarantee accurate results (e.g., Baczynski et al., 2019).

Consequently, the following four criteria have been used in this study to evaluate the significance of the $\delta^{13} \mathrm{C}_{\text {org }}$ profiles: (1) $\delta^{13} \mathrm{C}_{\text {org }}$ values from pre-PETM deposits vary between -22 and $-25 \%$ and those from PETM deposits between -25 and $-27 \%$, a criterion previously used, for instance, by Yans et al. (2014) and Maufrangeas et al. (2020) in sections of the northern Pyrenees; (2) the onset of the CIE entails a sustained shift of -2 to $-3 \%$; (3) comparisons between different $\delta^{13} \mathrm{C}_{\text {org }}$ isotopic profiles of the area, as well as with $\delta^{13} \mathrm{C}_{\text {carb }}$ profiles when available; (4) last, but not least, field relationships of the studied sections were taken into account.

The isotopic profiles obtained independently by Schmitz and Pujalte (2003) and Manners et al. (2013) in the Esplugafreda section exemplify the application of these criteria (Supplementary Fig. 2). Thus, $\delta^{13} \mathrm{C}_{\text {org }}$ values ranging from -21.5 to $-23.5 \%$ were considered pre-PETM and those between -24.9 and 26.5\% ascribed to the PETM by Manners et al. (2013). However, a 1.5\%o shift found by the Manners et al. (2013) between the Esplugafreda Formation and the incised valley fill deposits was considered of no significance. Likewise, a $\sim 2 \%$ shift in $\delta^{13} \mathrm{C}_{\text {carb }}$ profile found by Schmitz and Pujalte (2003) 70 m below the CC was dismissed on the same basis. However, both studies constrained the PETM to the same interval of the Esplugafreda section, mutually reinforcing the validity of independent criteria. 
410 An application of the aforementioned criteria in the study area reveals that the isotopic shift most likely associated to the onset of the CIE is the one recorded in the uppermost part of the Esplugafreda section in the Ad-S and Ad- $\mathrm{N}_{1}$ sections of the St Adria valley (Figs. 10B, 11B). This shift, which is based on high-resolution $\delta^{13} \mathrm{C}_{\text {org }}$ profiles, is both gradual and persistent, its shape and magnitude (2-4\%) being similar to the one found in terrestrial sections elsewhere (e.g., Baczynski et al., 2013). Finally, this shift is situated in the position predicted in the low resolution $\delta^{13} \mathrm{C}_{\text {carb }}$ profile reported by the Schmitz and Pujalte (2003) in another section of the St Adria valley (Fig. 2D, Supplementary Fig. 3B).

419 In the other section studied in this valley (Ad-N $\mathrm{N}_{2}$; Figs. $\left.11 \mathrm{D}\right) \delta^{13} \mathrm{C}_{\text {org }}$ values from the 420 Esplugafreda Formation provide pre-PETM values (-23 to -24\%), and those of the 421 Yellowish Soils PETM values (-26.1\%o on average). However, the gradual shift which marks the CIE onset in the Ad-S and Ad- $\mathrm{N}_{1}$ sections is not recorded, a fact readily attributable to the truncation of the top of the Esplugafreda section by a calcarenite 424 channel.

Field evidence indicates that the top of the $\mathrm{CC}$ in the Tendrui sector is situated $\sim 1 \mathrm{~m}$ below the base of the Yellowish Soils in the adjacent St. Adria sector (Fig. 11A).

427 Consequently, the CIE onset proposed by DMD (09-19) would be located about $11 \mathrm{~m}$ lower than its actual position in the Ad-S and the Ad- $\mathrm{N}_{1}$ sections (Figs. 12C, 13), which is unrealistic. On top of that, the $\delta^{13} \mathrm{C}_{\text {org }}$ profile of the $\mathrm{T}_{\mathrm{DMD}}$ is controversial because of the following facts: (1) average $\delta_{13} \mathrm{C}_{\text {org }}$ values of the alleged pre-PETM and PETM segments of the Esplugafreda Formation only differ by $0.7 \%$ (25.0\%o and $25.7 \%$, respectively), a shift much smaller than the one expected for the CIE onset; (2) although $\delta_{13} \mathrm{C}_{\text {org }}$ values lower than $-25 \%$, typical of the PETM, are dominant in the upper $8 \mathrm{~m}$ of 
434 Esplugafreda Formation, similar values also occur in about half of the samples from the pre-PETM interval; (3) given the proximity of the $\mathrm{T}_{\mathrm{DMD}}$ and $\mathrm{T}_{\mathrm{dt}}$ sections (Fig. 12A), $\delta_{13} C_{\text {org }}$ values of their supposed PETM intervals should be similar but they do differ by $-1.1 \%$ on average, and the values of the latter ( -24 to $-25.2 \%$ ) match those of the prePETM segment of the former (Figs. 12C, E, 13).

The reason why $\delta^{13} \mathrm{C}_{\text {org }}$ values from the upper part of the Esplugafreda Formation in the $\mathrm{T}_{\mathrm{DMD}}$ and Tdt sections are more negative than in coeval deposits of the St Adria valley still needs to be investigated. One possibility is that sediments from the $\mathrm{T}_{\mathrm{DMD}}$ section contain a high proportion of resedimented fossil carbon depleted in ${ }^{13} \mathrm{C}$. In that case, however, the isotopic composition of the $8 \mathrm{~m}$ interval of the Esplugafreda Formation situated below the $\mathrm{CC}$ in the $\mathrm{T}_{\mathrm{DMD}}$ and $\mathrm{T}_{\mathrm{dt}}$ sections should be similar, which is not the case. An alternative scenario could be that the $\delta_{13} \mathrm{C}_{\text {org }}$ values of the samples collected in the vegetated $\mathrm{T}_{\mathrm{DMD}}$ ravine have been tainted by recent root traces, as hinted by the uppermost sample collected from the vegetated part of the $\mathrm{T}_{\mathrm{dt}}$ section. Whatever the case, the above facts strongly suggest that the $\delta^{13} \mathrm{C}_{\text {org }}$ profiles of the $\mathrm{T}_{\mathrm{DMD}}$ and $\mathrm{T}_{\mathrm{dt}}$ sections do not faithfully record the global trend and, consequently, are not well suited to fix the position of the CIE onset.

In the Claret sector the marked erosional character of the base of the $\mathrm{CC}$ (Supplementary Fig. 3A) suggests also an encasement of the unit, but the total amount of the erosion into the underlying deposits cannot be quantified. Therefore, the possible

454 preservation of the CIE onset in this sector can only be appraised through an inspection 455 of continuous isotopic profiles. Such an inspection cannot be carried out in the Claret road section, since no samples can be retrieved from the 2-m-thick covered interval below the CC (Figs. 7, 8, 13). 
The Claret north and Claret hamlet sections, in which the boundary between the incised valley fill and the $\mathrm{CC}$ is well exposed, offer a better chance (Figs. 6, 13). In the former, pre-PETM $\delta_{13} \mathrm{C}_{\text {org }}$ values (-22.0 to $-22.9 \%$ ) persist in the grey calcarenites and marls until $20 \mathrm{~cm}$ below the CC base, where a single value of $-25.2 \%$ was obtained (Figs. 6A, 13). Should it mark the CIE isotope shift, the PETM onset would be situated just about $20 \mathrm{~cm}$ below the CC. However, the return to less negative $\delta_{13} \mathrm{C}_{\text {org }}$ values higher up (24.2 to $-22.3 \%$ ) argues against the $-25.2 \%$ value as the initiation of a persistent shift. Alternatively, this very negative value might be attributed to the recent alteration observable in the sediments situated immediately below the CC (Supplementary Fig. $3 \mathrm{~A})$.

As explained before, the red mudstones of the Claret hamlet section are thought to record the final infilling of the incised valley. If this interpretation proves correct, they post-date the grey calcarenites and marls of the Claret north section. The four samples analyzed from these red mudstones provided pre-PETM $\delta_{13} \mathrm{C}_{\text {org }}$ values, from -24.4 to $23.9 \%_{0}(-24.1 \%$ on average; Figs. $6 \mathrm{~B}$ and 13$)$. The $\delta_{13} \mathrm{C}_{\text {carb }}$ values reported by Pujalte et al. (2009) from three calcareous soil nodules from these red mudstones are also clearly pre-PETM (-7.5\%; Supplementary Fig 3B). Therefore, no clear evidence of the CIE onset can be discerned in any of the sections of the Claret sector.

\subsection{Sedimentary response to the PETM hydrological change}

477 Given that the development of extensive alluvial accumulations cannot be instantaneous, some time must have elapsed from the onset of the PETM hydrological change to the arrival of CC gravels and Yellowish Soils sediments to the study area, as

480 further demonstrated by the progradacional character of the $\mathrm{CC}$. The duration of the delay was quantified by DMD (09-19) in 9-16 kyr in the Claret road section and in 13- 
$24 \mathrm{kyr}$ in the $\mathrm{T}_{\mathrm{DMD}}$ section, based on the CIE onset assumed in each of them. However, according to the data discussed above, their assumption has been proven incorrect in the former section and is highly uncertain in the latter.

The information obtained in this study offers the possibility to circumvent these two problematic sections by focusing on the base of the Yellowish Soils in the sections in which the $\mathrm{CC}$ is absent, rather than on the CC itself. In effect, based on Walther's Law of Facies, it is reasonable to assume that the first Yellowish marls reached the study area at approximately the same time as the $\mathrm{CC}$, if not before.

The Ad-S and Ad- $\mathrm{N}_{1}$ sections provide sound evidence that the onset of the CIE is situated $\sim 1 \mathrm{~m}$ below the base of the Yellowish Soils (Figs. 10D, 11B). The exact duration of this interval cannot be calculated with available methods and, therefore, it has been tentatively estimated by assuming the same sedimentation rate as across the PETM core. This procedure, although admittedly inexact, has the advantage of permitting a direct comparison with the estimates of DMD (09-19).

The duration of the PETM onset and core was calculated in $80 \mathrm{kyr}$ by Bowen et al. (2004) and Röhl et al. (2007). In the Ad-S and Ad-N1 sections the onset and core of the PETM are represented by the topmost $1 \mathrm{~m}$ of the Esplugafreda Formation plus the $20 \mathrm{~m}$ thick Yellowish Soils. Their 21 m cumulative thickness (compacted), therefore, implies an average sedimentation rate of $26.25 \mathrm{~cm} \mathrm{kry}^{-1}$. The $1 \mathrm{~m}$ thick segment of the PETM onset preceding the accumulation of the Yellowish Soils to the study area consequently represents $\sim 3.8 \mathrm{kyr}$, less than half of the lowest estimate of DMD (09-19) and about one sixth of their highest one. Interestingly, following a completely different approach, 504 Zeebe et al. (2016) calculated that the carbon release during the PETM onset lasted $\sim 4$ kyr, a similar figure to the one estimated herein. 
506 Since the source area of the Garumnian alluvium was situated about $15 \mathrm{~km}$ to the north-

507 east from the study area (Supplementary Fig. 1) this figure entails an averaged

508 expansion rate of the extensive PETM depositional system of about $4 \mathrm{~km} / \mathrm{kyr}$. It is

509 unlikely, however, that such expansion rate was uniform throughout the $\sim 3.8 \mathrm{kyr}$ of the

510 CIE onset, since the shape of the initial isotope excursion clearly indicates a slow

511 increment of light carbon (Figs. 10D, 11B) and the climate response to warming is

512 slightly delayed (Zeebe et al., 2016). Also, both the temperature rise and the

513 concomitant increase of extreme rainfall episodes during the ongoing anthropogenic

514 warming of the Earth are being gradual (Shukla and Sen, 2021). Similar gradual

515 increases, therefore, may have occurred during the onset of the PETM. Consequently, it

516 is to be expected that the sedimentary expansion rate of the PETM alluvial system may

517 have been slow at first and progressively accelerated in parallel with the $\mathrm{CO}_{2}$ emission

518 and the intensification of the warming. Whatever the case, the response of the

519 sedimentary system to the PETM hydrological change seems to have been, in geological

520 terms, comparatively rapid.

\section{6. Conclusions}

522 The claim that the sedimentary response to the PETM hydrological change in the south

523 Pyrenean Tremp-Graus Basin was delayed by $16.5 \pm 7.5 \mathrm{kyr}$ is challenged with new field

524 and organic carbon isotope data. This claim was based on the assertion that the onset of

525 the CIE was recorded 3 and $8 \mathrm{~m}$ below the $\mathrm{CC}$ in the Claret and Tendrui sections.

526 However, new field data and organic carbon isotopic analyses of one hundred samples

527 from eight sections, including the two conflicting ones, lead to a different conclusion.

528 Field mapping and observations demonstrate that at Claret, Tendrui and elsewhere in

529 the study area, the CC is erosively encased within the underlying deposits and is

530 laterally discontinuous. In two sections in which the $\mathrm{CC}$ is absent and the Yellowish 
531 Soils conformably rest on the Esplugafreda Formation, coded Ad-S and Ad- $\mathrm{N}_{1}$, the

532 onset of the CIE has been confidently pinpointed about $1 \mathrm{~m}$ below the base of the

533 Yellowish Soils. This onset, however, is truncated by the CC erosional base at the

534 Claret and Tendrui sections, making them unsuitable for any chronological

535 reconstructions.

536 As the expansion of alluvial systems cannot be instantaneous, some time must have

537 elapsed between the onset of the hydrological change and the arrival of PETM alluvium

538 to the study area. In fact, the internal architecture of the $\mathrm{CC}$, indicative of intermittent

539 progradation, entails a progressive development. A tentative estimate, based on

540 sedimentation rates, suggests that the arrival of PETM alluvium to the Claret-Tendrui

541 area occurred $\sim 3.8 \mathrm{kyr}$, after the onset of the CIE, about a third of the lowest estimate of

542 previous authors. Since the study area was situated about $15 \mathrm{~km}$ from the source area,

543 this new estimate entails a minimum expansion rate of about $4 \mathrm{~km} \mathrm{kyr}^{1}$ and supports a

544 rapid environmental response of the sedimentary system to the PETM hydrological

545 change.

\section{Acknowledgements}

547 Research by VP and AP was supported by MINECO/MCI/FEDER-UE projects

548 CGL2015-65404-R and PID2019-105670GB-I00/AEI/10.13039/501100011033 of the

549 Spanish Government, and by the Consolidated Research Group IT930-16 of the Basque

550 Government. Research by BS was supported by the Swedish Research Council.

\section{$551 \quad$ References}

552 Allen, P. A., 2017. The sediment routing systems: the fate of sediments from source to sink. Cambridge University Press, 403 pp. 
Armitage, J. J., Duller, R. A., Whittaker, A.C., Allen P. A., 2011. Transformation of tectonic and climatic signals from source to sedimentary archive. Nat. Geosci 4, 231-235 doi:10.1038/ngeo1087.

Armitage, J. J., Dunkley Jones, T., Duller, R. A., Whittaker, A. C., Allen, P. A., 2013. Temporal buffering of climate-driven sediment flux cycles by transient catchment response, Earth and Planetary Science Letters, 369-370, 200-210, doi: 10.1016/j.epsl.2013.03.020, 2013.

Baceta, J., Pujalte, V., Wright, V.P., Schmitz, B., 2011. Carbonate platform models, sea-level changes and extreme climatic events during the Paleocene-early Eocene greenhouse interval: a basin-platform-coastal plain transect across the southern Pyrenean basin. In: Pree-Meeting Field trips Guidebook, 28th IAS Meeting. Zaragoza (C. Arenas, L. Pomar and F. Colombo, Eds.). Sociedad Geológica de España, Geo-Guías, 7:151-198.

Baczynski, A. A., McInerney, F. A., Freeman, K. H., Wing, S. L., \& the Bighorn Basin Coring Project (BBCP) Science Team (2019). Carbon isotope record of trace $\mathrm{n}$-alkanes in a continental PETM section recovered by the Bighorn Basin Coring Project (BBCP). Paleoceanography and Paleoclimatology, 34, 1-13. https://doi.org/10.1029/2019PA003579

Baczynski, A.A., McInerney, F.A., Wing, S.L., Kraus, M.J., Bloch, J.I., Boyer, D.M., Secord, R., Morse, P.E., Fricke, H.C., 2013. Chemostratigraphic implications of spatial variation in the Paleocene-Eocene Thermal Maximum carbon isotope excursion, SE Bighorn Basin, Wyoming. Geochem. Geophys. 14, 4133-4152. doi: 10.1002/ggge.20265. 
Baczynski, A.A., McInerney, F.A., Wing, S.L., Kraus, M.J., Morse, P.E., Bloch, J. I., Chung, A. H., Freeman, K. H., 2016. Distortion of carbon isotope excursion in bulk soil organic matter during the Paleocene-Eocene thermal maximum. GSA Bulletin, 128, 1352-1366. doi:10.1130/B31389.1

Bowen, G.J., Beerling, D.J., Koch, P.L., Zachos, J.C., and Quattlebaum, T., 2004, A humid climate state during the Palaeocene-Eocene thermal maximum: Nature, v. 432, p. 495-499, doi:10.1038/nature03115.

Capel Molina, J., 1974. Génesis de las inundaciones de Octubre de 1973 en el Sureste de la Península Ibérica. Cuad. Geog., 4, 140-166

Carmichael, M. J., Inglis, G. N., Badger, M. P. S., Naafs, D. A., Behrooza, L., Remmelzwaal, S., Monteiro, F. M., Rohrssen, M., Farnsworth, A., Buss, H. L., Dickson, A. J., Valdes, P.J., Lunt, D. J., Pancost, R. D., 2017. Hydrological and associated biogeochemical consequences of rapid global warming during the Paleocene-Eocene Thermal Maximum. Gloplacha, 157, 114-138. https://doi.org/10.1016/j.gloplacha.2017.07.014

Carmichael, M. J., Pancost, R. D., Lunt, D. J., 2018. Changes in the occurrence of extreme precipitation events at the Paleocene-Eocene thermal maximum. Earth Planet. Sci. Lett. 501, 24-36. https://doi.org/10.1016/j.epsl.2018.08.005

Colombera, L., Arévalo, O. J., Mountney, N. P., 2017. Fluvial-system response to climate change: The Paleocene-Eocene Tremp Group, Pyrenees, Spain. Gloplacha 157, 1-17. https://doi.org/10.1016/j.gloplacha.2017.08.011

Cuevas, J.L., 1992. Estratigrafía del "Garumniense” de la Conca de Tremp. Prepirineo de Lérida. Acta Geol. Hisp. 27, 95-108. 
Deser, C., Lehner, F., Rodgers, K.B.. Ault, T., Delworth, T.L., DiNezio, P.N., Fiore, A., Frankignoul, C., Fyfe, J.C., Horton, D.E., Kay, J.E., Knutti, R., Lovenduski, N.S., Marotzke, J., McKinnon, K.A., Minobe, S., Randerson, J., Screen, J.A., Simpson I.R., Ting. M., 2020. Insights from Earth system model initial-condition large ensembles and future prospects. Nat. Clim. Chang. 10, 277-286 https://doi.org/10.1038/s41558-020-0731-2

Domingo, L., López-Martínez, N., Leng, M. J., Grimes, S.T., 2009. The PaleoceneEocene Thermal Maximum record in the organic matter of the Claret and Tendruy continental sections (South-central Pyrenees, Lleida, Spain). Earth Planet. Sci. Lett. 281, 226-237. https://doi.org/10.1016/j.epsl.2009.02.025

Duller, R.A., Armitage, J.J., Hayley R. Manners, H.R., Grimes, S., Dunkley Jones, J., 2019. Delayed sedimentary response to abrupt climate change at the PaleoceneEocene boundary, northern Spain. Geology 47, 159-162, https://doi.org/10.1130/G45631.1

Foreman, B.Z., 2014. Climate-driven generation of a fluvial sheet sand body at the Paleocene-Eocene boundary in north-west Wyoming (USA). Basin Res. 26, 225241. https://doi.org/10.1111/bre.12027

Foreman, B.Z., Heller, P. L., Clementz, M. T., 2012. Fluvial response to abrupt global warming at the Palaeocene/Eocene boundary. Nature 491, 92-95. https://doi.org/10.1038/nature11513García Veigas, J., 1997. First Continental Evaporitic Phase in the South Pyrenean Central Area: Tremp Gypsum (Garumn Facies, Upper Paleocene; Allochtonous Zone). In: Busson, G., Schreiber, B.Ch. (Eds.), Sedimentary Deposition in Rift and Foreland Basins in France and Spain (Paleogene and Lower Neogene). Columbia University Press, pp. 335-342. 
García Veigas, J., 1997. First Continental Evaporitic Phase in the South Pyrenean Central Area: Tremp Gypsum (Garumn Facies, Upper Paleocene; Allochtonous Zone). In: Busson, G., Schreiber, B.Ch. (Eds.), Sedimentary Deposition in Rift and Foreland Basins in France and Spain (Paleogene and Lower Neogene). Columbia University Press, pp. 335-342.

Gibson, T. G., Bybell, L. M., Mason, D. B., 2000. Stratigraphic and climatic implications of clay mineral changes around the Paleocene/Eocene boundary of the northeastern US margin. Sedim. Geol. 134, 65-92. https://doi.org/10.1016/S00370738(00)00014-2

Handley, L., O’Halloran, A., Pearson, P. N., Hawkins, E., Nicholas, C.J., Schouten, S., McMillan, I. K., Pancost, R. D., 2012. Changes in the hydrological cycle in tropical East Africa during the Paleocene-Eocene Thermal Maximum. Palaeogeogr. Palaeoclimatol. Palaeoecol. 329,10-21, http://dx.doi.org/10.1016/j.palaeo.2012.02.002.

Held. I.M., Soden B.J., (2006) Robust Responses of the Hydrological Cycle to Global Warming. J. Clim. 19, 5686-5699. https://doi.org/10.1175/JCLI3990.1

Hernández-Molina, F. J., Somoza, L., Vázquez, J. T., Rey, J. 1995. Estructuración de los prismas litorales del Cabo de Gata: respuesta a los cambios climático-eustáticos holocenos. Geogaceta, 18, 79-82

Jiang, J., Hu, X., Li, J., BouDagher-Fadel, M., Garzanti, E., 2021. Enhanced hydrological change during the Paleocene-Eocene thermal maximum (PETM) recorded in shallow-marine Xigaze forearc basin (southern Tibet). Palaeogeogr. Palaeoclimatol. Palaeoecol. 562 (2021), 110095. https://doi.org/10.1016/j.palaeo.2020.110095 
John, C.M., Bohaty, S.M., Zachos, J.C., Sluijs, A., Gibbs, S., Brinkhuis, H., Bralower, T.J., 2008. North American continental margin records of the Paleocene-Eocene thermal maximum: implications for global carbon and hydrological cycling. Paleoceanography 23, PA2217. doi:10.1029/2007PA001465

Koch, P.L., Zachos, J.C., Gingerich, P.D., 1992. Correlation between isotope records in marine and continental carbon reservoirs near the Paleocene/Eocene boundary. Nature 358, 319-322.

Kraus, M. J., McInerney, F. A., Wing, S. L., Secord, R., Baczynski, A. A., Bloch, J. I., 2013. Paleohydrologic response to continental warming during the PaleoceneEocene Thermal Maximum, Bighorn Basin, Wyoming. Palaeogeogr. Palaeoclimatol. Palaeoecol. 370, 196-208. doi: 10 .1016/j .palaeo .2012.12.008

Kraus, M.J., Woody, D.T., Smith, J.J., Dukic, V., 2015. Alluvial response to the Paleocene-Eocene Thermal Maximum climatic event, Polecat Bench,Wyoming (U.S.A.). Palaeogeogr. Palaeoclimatol. Palaeoecol 435, 177-192. https://doi.org/10.1016/j.palaeo.2015.06.021

Manners, H.R., Grimes, S.T., Sutton, P.A., Domingo, L., Leng, M.J., Twitchett, R.J., Hart, M.B., Dunkley Jones, T., Pancost, R.D., Duller, R., Lopez-Martinez, N., 2013. Magnitude and profile of organic carbon isotope records from the PaleoceneEoceneThermal Maximum: evidence from northern Spain. Earth Planet. Sci. Lett. 376, 220-230. http://dx.doi.org/10.1016/j.eps1.2013.06.016

Maufrangeas, A., Leleu, S., Loisy, C., Roperch, P., Jolley, D., Vinciguerra C., NguyenThuyet, O., 2020. Stratigraphy of the Paleocene continental sedimentary succession of the northern Pyrenean basin (Corbières, southern France) using $\delta^{13} \mathrm{C}_{\text {org }}$ isotopes. J. Geol. Soc. London, 177, 752-765, https://doi.org/10.1144/jgs2019-084 
672 McInerney, F.A., Wing, S.L., 2011. The Paleocene Eocene ThermalMaximum: a

673 perturbation of carbon cycle, climate, and biosphere with implications for the

674 future. Annu. Rev. Earth Planet. Sci 39, 489-516. DOI: 10.1146/annurev-earth-

675 040610-133431

676

677

678

679

680

681

682

683

684

685

686

687

688

689

690

691

692

693

694

Minelli, N., Manzi, V., Roveri, M. 2013. The record of the Paleocene-Eocene thermal maximum in the Ager Basin (Central Pyrenees, Spain). Geol. Acta, 11, 421-441. DOI: $10.1344 / 105.000002061$

Pancost, R.D., 2017. Climate change narratives. Nature Geoscience, 10, 466-468.

Payros, A., Pujalte, V., Orue-Etxebarria, X., Apellaniz, E., Bernaola, G., Baceta, J.I., Caballero, F., Dinarés-Turell, J., Monechi, S., Ortiz, S., Schmitz, B., Tosquella, J., 2016. The Relevance of Iberian Sedimentary Successions for Paleogene Stratigraphy and Timescales. In: Montenari, M. (Ed.), Stratigraphy \& Timescales, pp. 393-489.

Plink-Björklund P., Birgeneier L., Jones E, 2014. Extremely bad early Eocene weather: Evidence for extreme precipitation from rived deposits. Rendiconti Online della Soc. Geol. It. 31, 175-176. doi: 10.3301/ROL.2014.107

Pujalte, V., Baceta, J.I., Schmitz, B., Orue-Etxebarria, X., Payros, A., Bernaola, G., Apellaniz, E., Caballero, F., Serra-Kiel, J., Tosquella, J., 2009. Redefinition of the Ilerdian Stage (early Eocene). Geol. Acta 7, 177-194. https://doi.org/10.1344/105.000000268

Pujalte, V., Robador, A., A., Samsó, J.Mª 2016. A siliciclastic braid delta within a lower Paleogene carbonate platform (Ordesa-Monte Perdido National Park, southern Pyrenees, Spain): Record of the Paleocene-Eocene Thermal Maximum 
perturbation. Palaeogeogr. Palaeoclimatol. Palaeoecol., 459, 453-470. http://dx.doi.org/10.1016/j.palaeo.2016.07.029

697

698

699

700

701

702

703

704

705

706

707

708

709

710

711

712

713

714

715

716

Pujalte, V., Schmitz, B., 2005. Revisión de la estratigrafía del Grupo Tremp (“Garumniense”, Cuenca de Tremp-Graus, Pirineos meridionales). Geogaceta 38, 79-82.

Pujalte, V., Schmitz, B., 2014. Comment on "Magnitude and profile of organic carbon isotope records from the Paleocene-Eocene Thermal Maximum: evidence from northern Spain" by Manners et al. [Earth Planet. Sci. Lett. 376 (2013) 220-230]. Earth Planet. Sci. Lett. 395, 291-293. https://doi.org/10.1016/j.eps1.2014.03.054

Pujalte, V., Schmitz, B., 2019. Record of the Paleocene-Eocene Thermal Maximum in the Southern and Western Pyrenees. In: C. Quesada and J. T. Oliveira (eds.), The Geology of Iberia: A Geodynamic Approach, Springer Nature Switzerland AG. pp. 13-17. https://doi.org/10.1007/978-3-030-11190-8_2.

Pujalte, V., Schmitz, B., Baceta, J.I., 2014. Sea-level changes across the PaleoceneEocene interval in the Spanish Pyrenees, and their possible relationship with North Atlantic magmatism. Palaeogeogr. Palaeoclimatol. Palaeoecol. 393, 45-60. https://doi.org/10.1016/j.palaeo.2013.10.016

Röhl, U., Westerhold, T., Bralower, T.J., Zachos, J.C., 2007. On the duration of the Paleocene- Eocene Thermal Maximum (PETM). Geochem. Geophys. Geosyst. 8, 113. https://doi.org/10.1029/2007GC001784.

Rosell, J., Linares, R., Llompart, C., 2001. El “Garumniense” prepirenaico. Rev. Soc. Geol. Esp. 14, 47-56. 
Schmitz, B., Pujalte, V., 2003. Sea-level, humidity, and land-erosion records across the initial Eocene thermal maximum from a continental-marine transect in northern Spain. Geology 31, 689-692. doi:https://doi.org/10.1130/G19527.1

Schmitz, B., Pujalte, V., 2007. Abrupt increase in seasonal extreme precipitation at the Paleocene-Eocene boundary. Geology 35, 215-218. doi:https://doi.org/10.1130/G23261A.1

Schmitz, B., Pujalte, V., Núñez-Betelu, K., 2001. Climate and sea-level perturbations during the Incipient Eocene Thermal Maximum: evidence from siliciclastic units in the Basque Basin (Ermua, Zumaia and Trabakua Pass), northern Spain. Palaeogeogr. Palaeoclimatol. Palaeoecol., 165, 299-320. https://doi.org/10.1016/S0031-0182(00)00167-X

Shukla, T. and Sen, I. S., 2021. Preparing for floods on the Third Pole. Science 372, 232-234. DOI: 10.1126/science.abh3558

Simpson, G., Castelltort, S., 2012. Model shows that rivers transmit high-frequency climate cycles to the sedimentary record. Geology 40, 1131-1134. doi:https://doi.org/10.1130/G33513.1

Slotnick, B.S., Dickens, G.R., Nicolo, M.J., Hollis, C.J., Crampton, J.S., Zachos, J.C., Sluijs, A., 2012. Large-amplitude variations in carbon cycling and terrestrial weathering during the Latest Paleocene and Earliest Eocene: the record at Mead Stream, New Zealand. J. Geol 120, 487-505. DOI: 10.1086/666743

Sluijs, A., Bowen, G.J., Brinkhuis, H.L., Lourens, J., Thomas, E., 2007. The Palaeocene-Eocene ThermalMaximum super greenhouse: biotic and geochemical signatures, age models and mechanisms of global change. In: Williams, M., Haywood, A.M., Gregory, F.J., Schmidt, D.N. (Eds.), Deep-Time Perspectives on 
Climate Change:Marrying the Signal from Computer Models and Biological Proxies. Special Publications, The Geological Society, London, The Micropalaeontological Society, pp. 323-349.

Storme, J.-Y., Devleeschouwer, X., Schnyder, J., Cambier, G., Baceta, J.I., Pujalte, V., Di Matteo, A., Iacumin, P., and Yans, J, 2012. The Palaeocene/Eocene boundary section at Zumaia (Basque-Cantabric Basin) revisited: new insights from highresolution magnetic susceptibility and carbon isotope chemostratigraphy on organic matter $\left(\delta^{13} \mathrm{C}_{\text {org }}\right)$, Terra Nova, 24, 310-317. doi: 10.1111/j.1365-3121.2012.01064.x

Yans, J., Marandat, B., Masure, E., Serra-Kiel, J., Schnyder, J., Storme J-Y., Marivaux, L., Adnet, S., Vianey-Liaud, M., Rodolphe Tabuce, R., 2014. Refined bio- (benthic foraminifera, dinoflagellate cysts $)$ and chemostratigraphy $\left(\delta^{13} \mathrm{C}_{\mathrm{org}}\right)$ of the earliest Eocene at Albas-Le Clot (Corbières, France): implications for mammalian biochronology in Southern Europe. Newsl Stratigr. 47 331-353. DOI: $10.1127 / \operatorname{nos} / 2014 / 0050$

Zachos, J. C.; Dickens, G. R.; and Zeebe, R. E. 2008. An early Cenozoic perspective on greenhouse warming and carbon-cycle dynamics. Nature 451 279-283. DOI: 10.1038/nature06588.

\section{Figure Captions}

Fig. 1. Abrupt expansion $(\sim 270 \mathrm{~m})$ of a small fan delta in the semiarid southeast coast of peninsular Spain during a single major flood $\left(2,580 \mathrm{~m}^{3} / \mathrm{seg}\right.$ at peak flow) after two days of heavy rain in October 1973.

Fig. 2. (A) Simplified early Paleogene palaeogeography of the Pyrenean domain. (B) Outcrop map of the east part of the Tremp-Graus Basin with location of the study area. 
(C) Outcrop map of the Paleocene-Eocene interval in the study area. (D) Simplified S-N section (projected) showing the location of sections and outcrops described in the text

767 (vertical scale exaggerated).

768

769

770

771

772

773

774

775

776

777

778

779

780

781

782

783

784

785

786

787

Fig. 3. Incised valley grey-coloured deposits at the Claret road section. (A) General view. (B) Close-up of the imbricated basal conglomerates of the valley fill. (C) Buried tree trunk in living position. (D) Abundant coal remains in a sample of the incised valley calcarenites.

Fig. 4. (A) Incised valley red calcareous mudstones directly overlain by the Claret Conglomerate. (B) Close-up of the altered zone of the red mudstones directly below the Claret Conglomerate.

Fig. 5. (A) Outcrop map of the Paleocene-Eocene boundary deposits in the Claret sector with indication of palaeocurrents and location of the Claret north section (illustrated in B) and the Palau creek section (illustrated in C).

Fig. 6. Close up views and $\delta^{13} \mathrm{C}_{\text {org }}$ values from the topmost part of the incised valley fill deposits of the Claret north (A) and the Claret hamlet (B) sections. Explanation within the text.

Fig. 7. (A) Map of the base and top of the CC drawn on a Google Earth satellite image of the area surrounding the Claret road section. Note that the $\mathrm{CC}$ base is hidden by vegetation throughout. $(\mathrm{B}, \mathrm{C})$ Field view and sketch of the upper part of the incised valley deposits, the poorly exposed CC and the intervening covered interval (location in A). Values of $\delta^{13} \mathrm{C}_{\text {org }}$ isotopes from incised valley deposits are indicated in the sketch.

Fig. 8. (A) Sketch of the CC in the Claret road section, drawn from field photos B-D. As the outcrop is situated on a road bend, the perspective of the successive photos is 
distorted. To alleviate the distortion, two characteristic points are marked in different pictures: a small yellow circle in B and C, and a circled fallen block (arrowed) in A, C and $\mathrm{D}$. The orange line (in the online version) marks the base of the same conglomeratic bed in all pictures. $\delta^{13} \mathrm{C}_{\text {org }}$ values from marly clays are shown in $\mathrm{A}$.

Fig. 9. (A) Close-up of the upper part of the Ad-S section. (B) Micrographs of a thin section of a purple cap sample illustrating two of its numerous ferruginous nodules.

Fig. 10. (A, B) Field views of two adjacent segments of the southern margin of the St Adria valley illustrating the encasement of the $\mathrm{CC}$ into the Esplugafreda Formation (location in Fig. 2C). (C) General view of the Ad-S section (location in A and B). (D) $\delta^{13} \mathrm{C}_{\text {org }}$ isotopic profile of the Ad-S section. (E) Field view of a calcarenite channel with its base party eroding the Esplugafreda Formation (location in B).

Fig. 11. (A) Field view of the northern margin of the St Adria valley and southern part of the Tendrui sector showing the location of the $\mathrm{Ad}-\mathrm{N}_{1}$ and $\mathrm{Ad}-\mathrm{N}_{2}$ sections, the treecovered CC of the Tendrui sector and the farm-land situated just above it. (B) Field view and isotope profile of the Ad- $\mathrm{N}_{1}$ section. The encircled hammer in the photo is situated on the purple cap. (C) Close-up of the Esplugafreda Formation red marls in the Ad- $\mathrm{N}_{1}$ section showing its numerous $\mathrm{CaCO}_{3}$ soil nodules (some encircled). (D) $\delta^{13} \mathrm{C}_{\text {org }}$ isotope profile of the $\mathrm{Ad}-\mathrm{N}_{2}$ section.

Fig. 12. (A) Field view of the northern part of the Tendrui sector with location of the $\mathrm{T}_{\mathrm{DMD}}$ and the $\mathrm{T}_{\mathrm{dt}}$ sections. Note abundant vegetation. $(\mathrm{B}, \mathrm{C})$ Field view and isotope profile of the $\mathrm{T}_{\mathrm{DMD}}$ section. $(\mathrm{D}, \mathrm{E})$ Field view and isotope profile of the $\mathrm{T}_{\mathrm{dt}}$ section. 
809 Fig. 13. Organic carbon isotope profiles from the P-E boundary sections analyzed in this

810 study. Note that values of the $\mathrm{T}_{\mathrm{DMD}}$ section are at odds with those of the other sections.

811 Explanation within the text. 
Before the flood

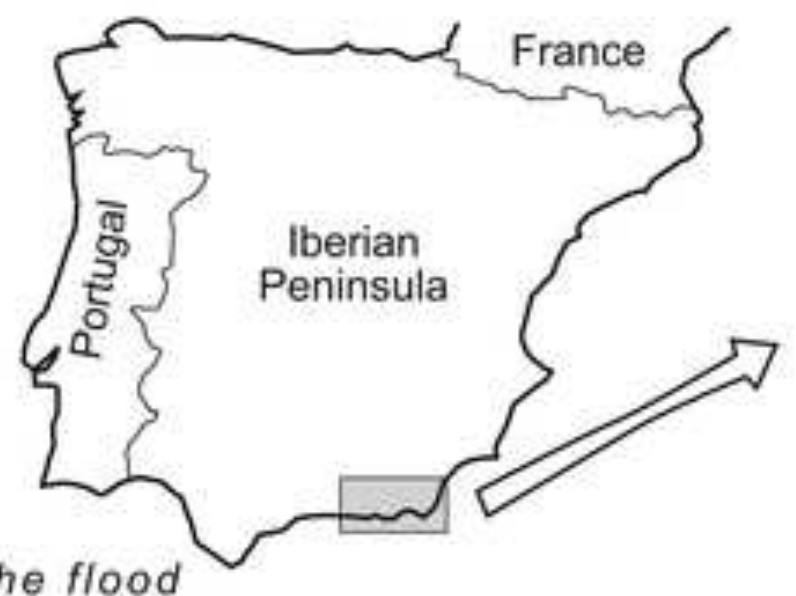

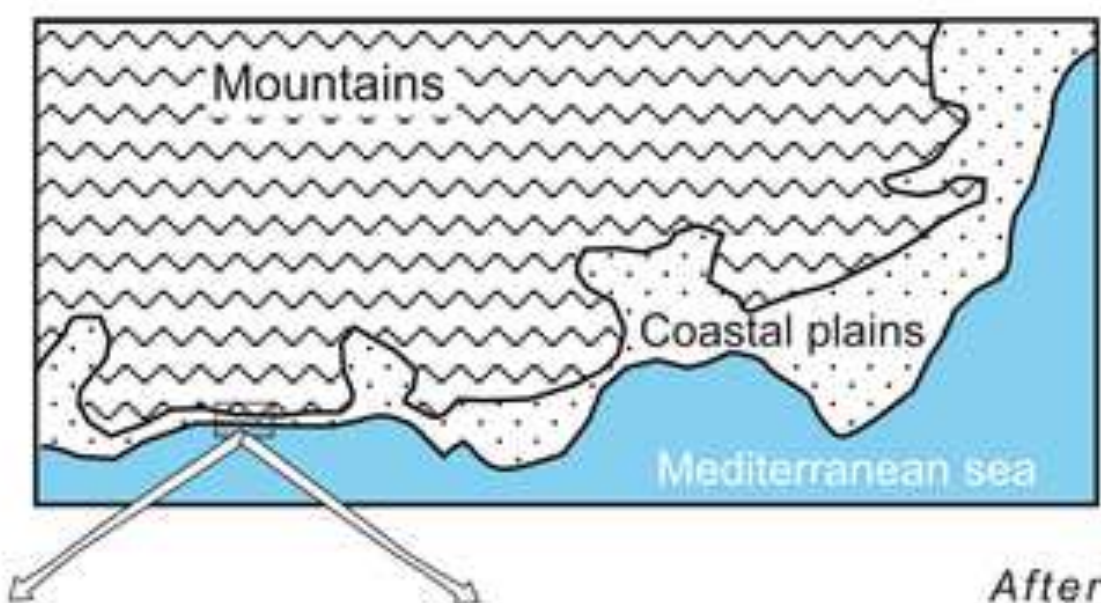

After the flood
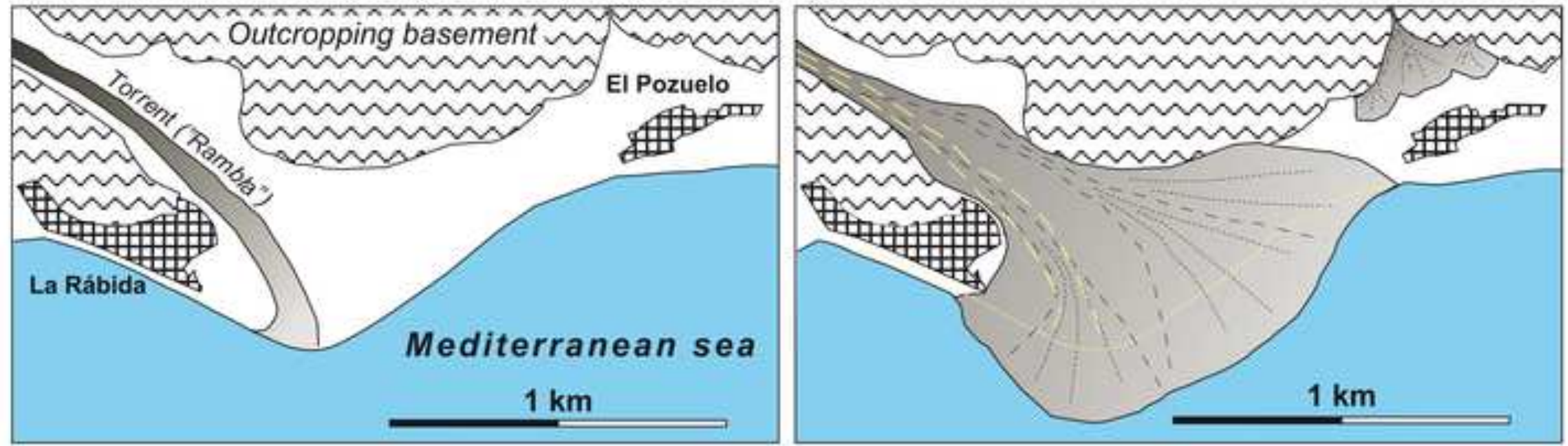

Pujalte et al Fig 1 


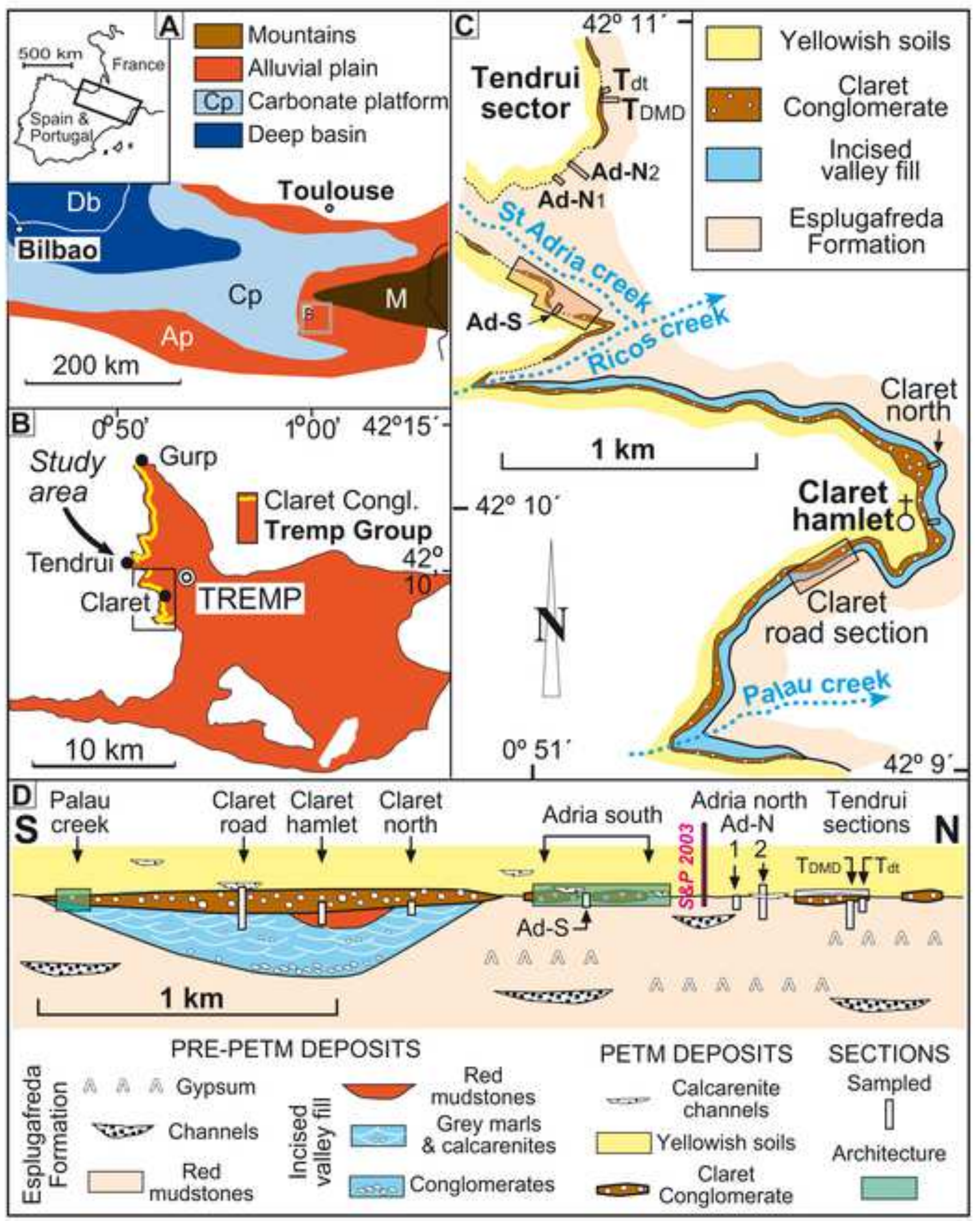



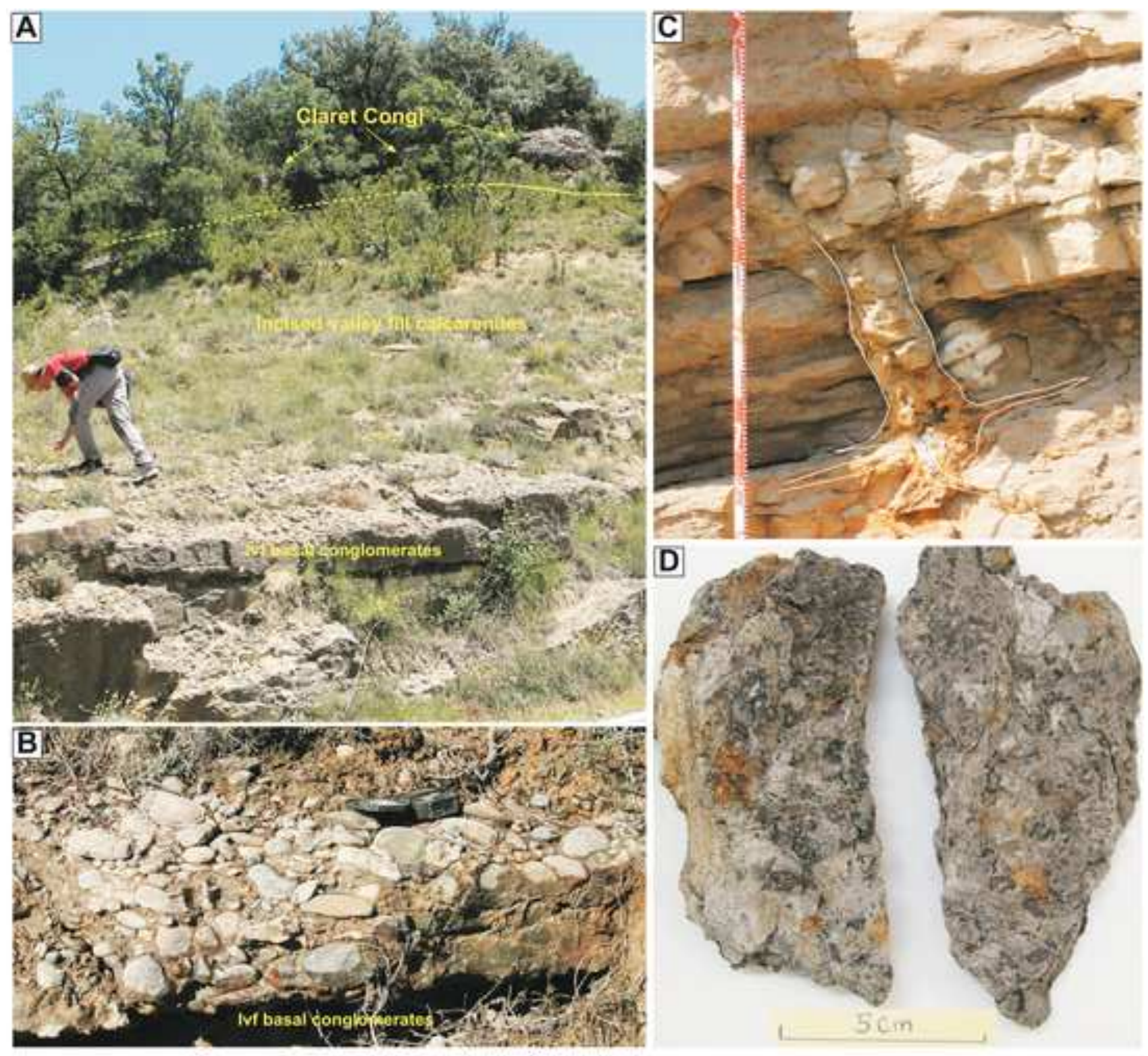

Pujalte et al Fig 3 

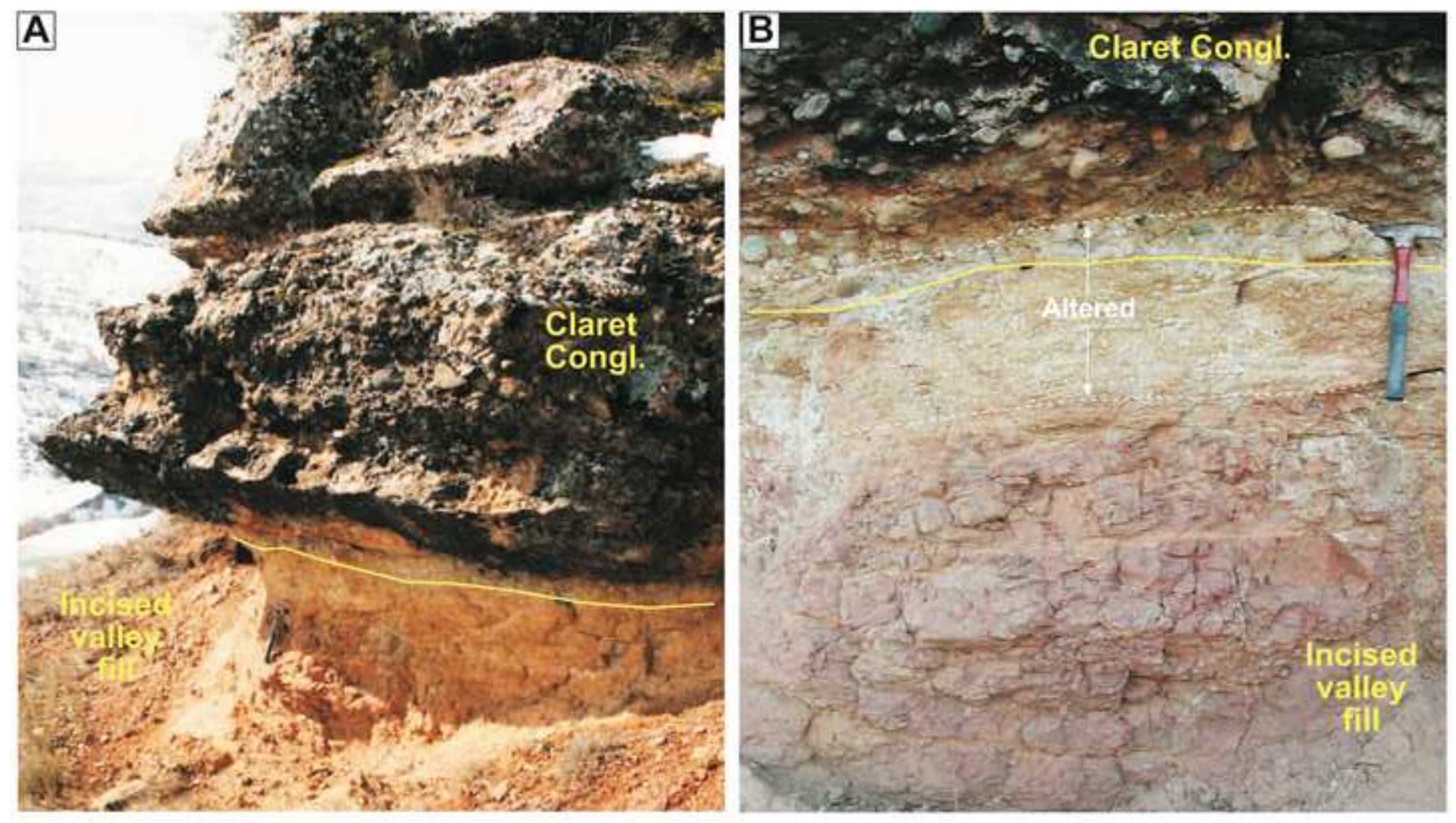

\section{Pujalte et al Fig 4}



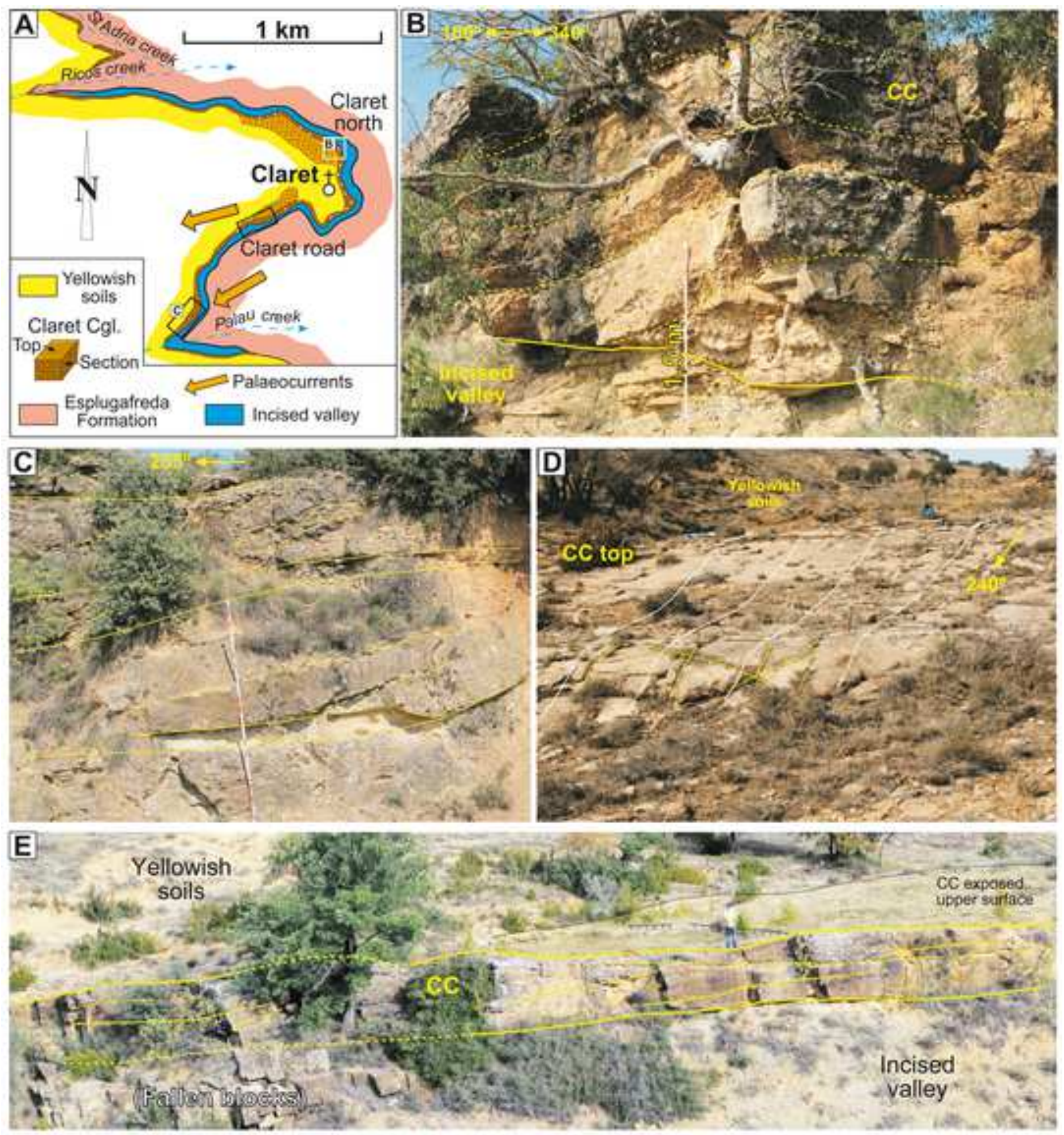

\section{Pujalte et al Fig 5}



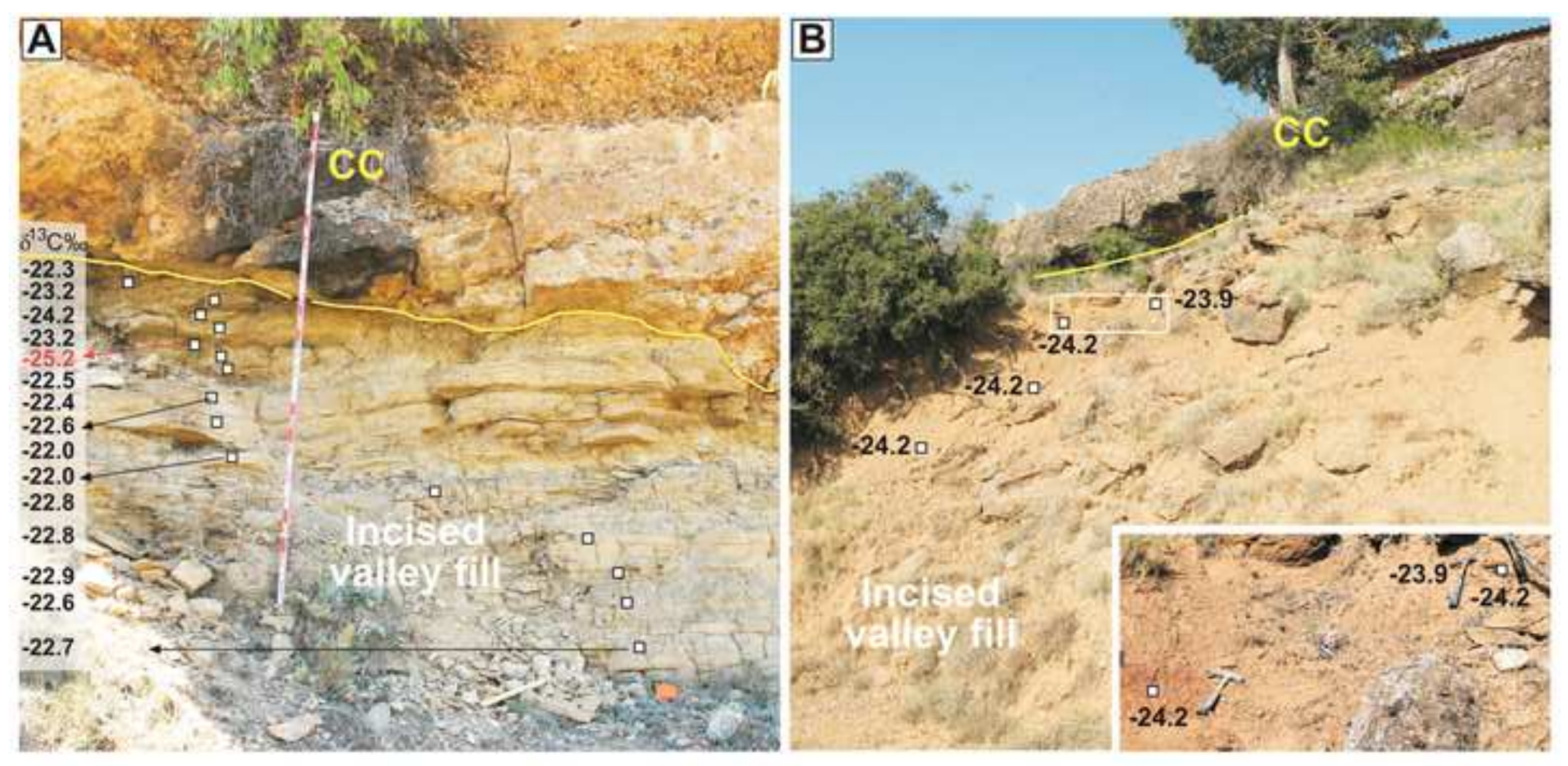

\section{Pujalte et al Fig 6}



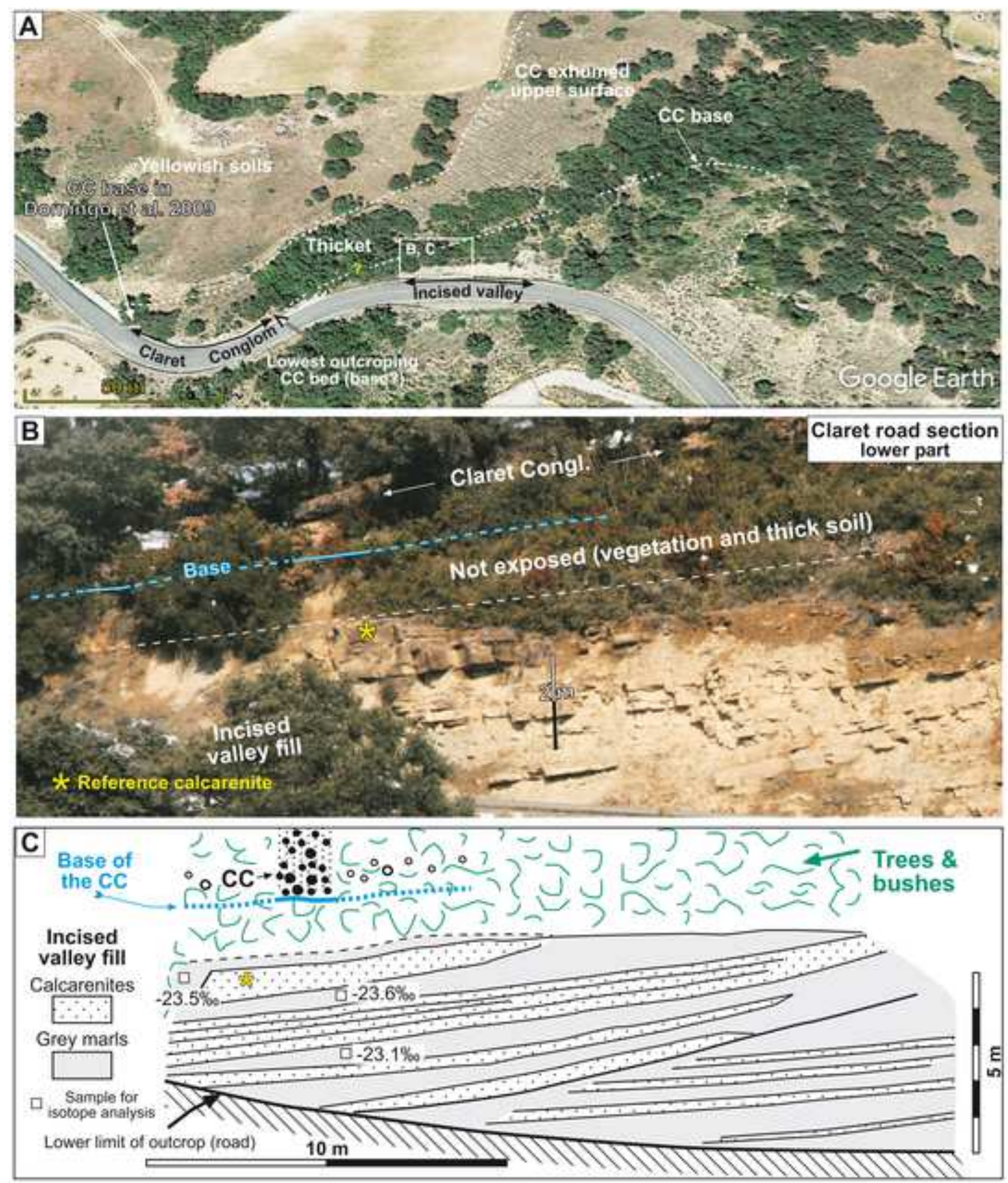

Pujalte et al Fig 7 

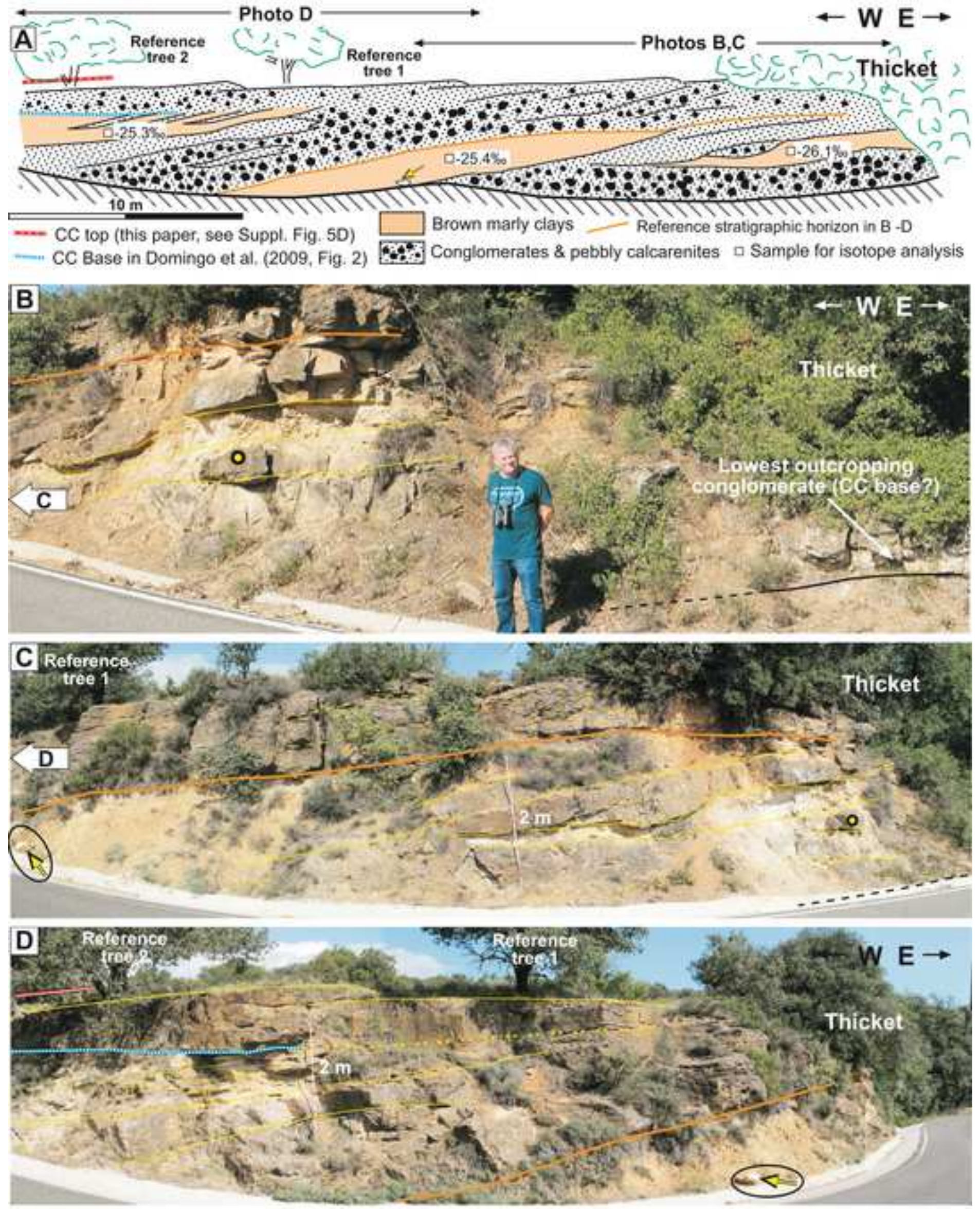

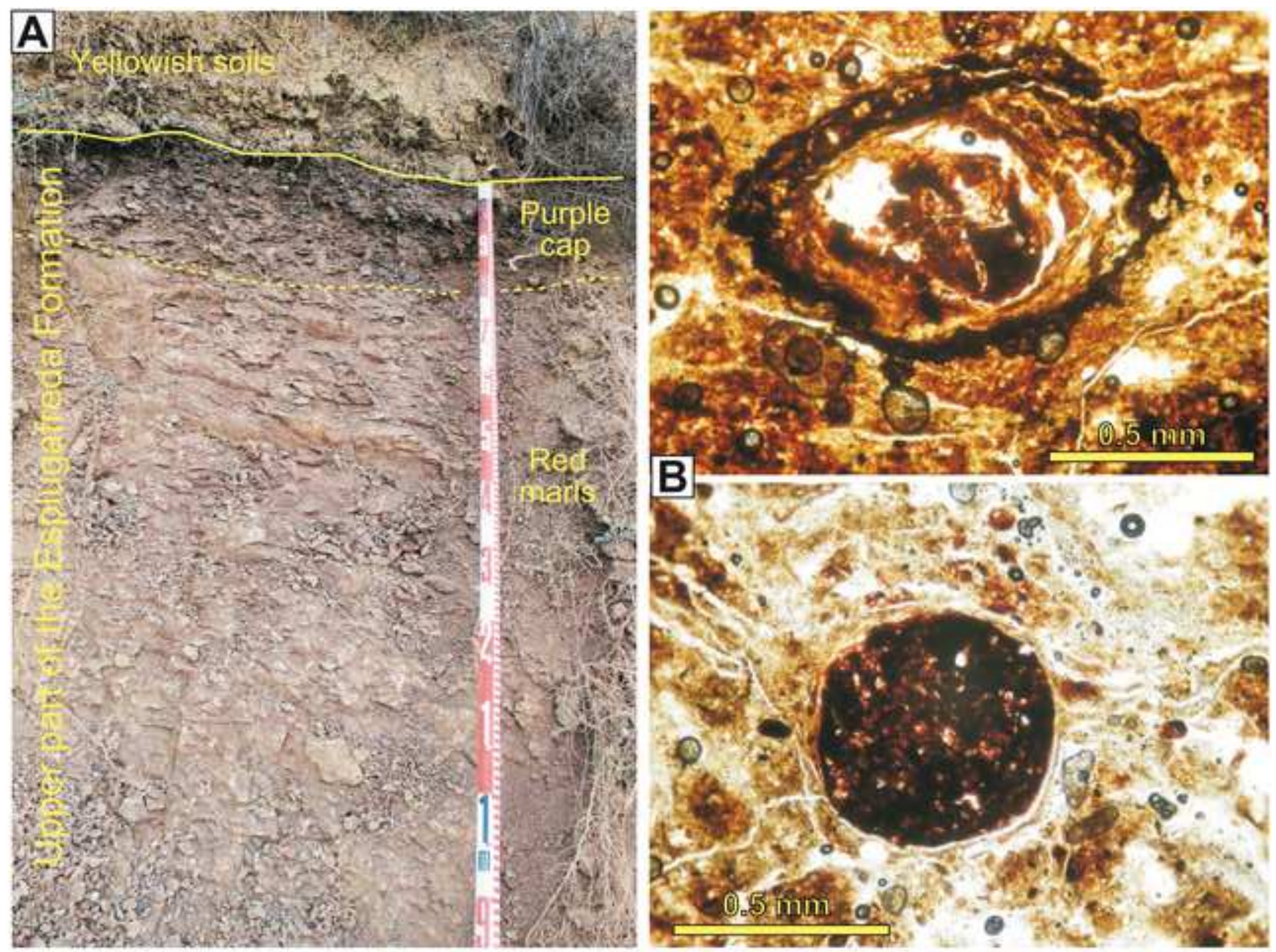

\section{Pujalte et al Fig 9}



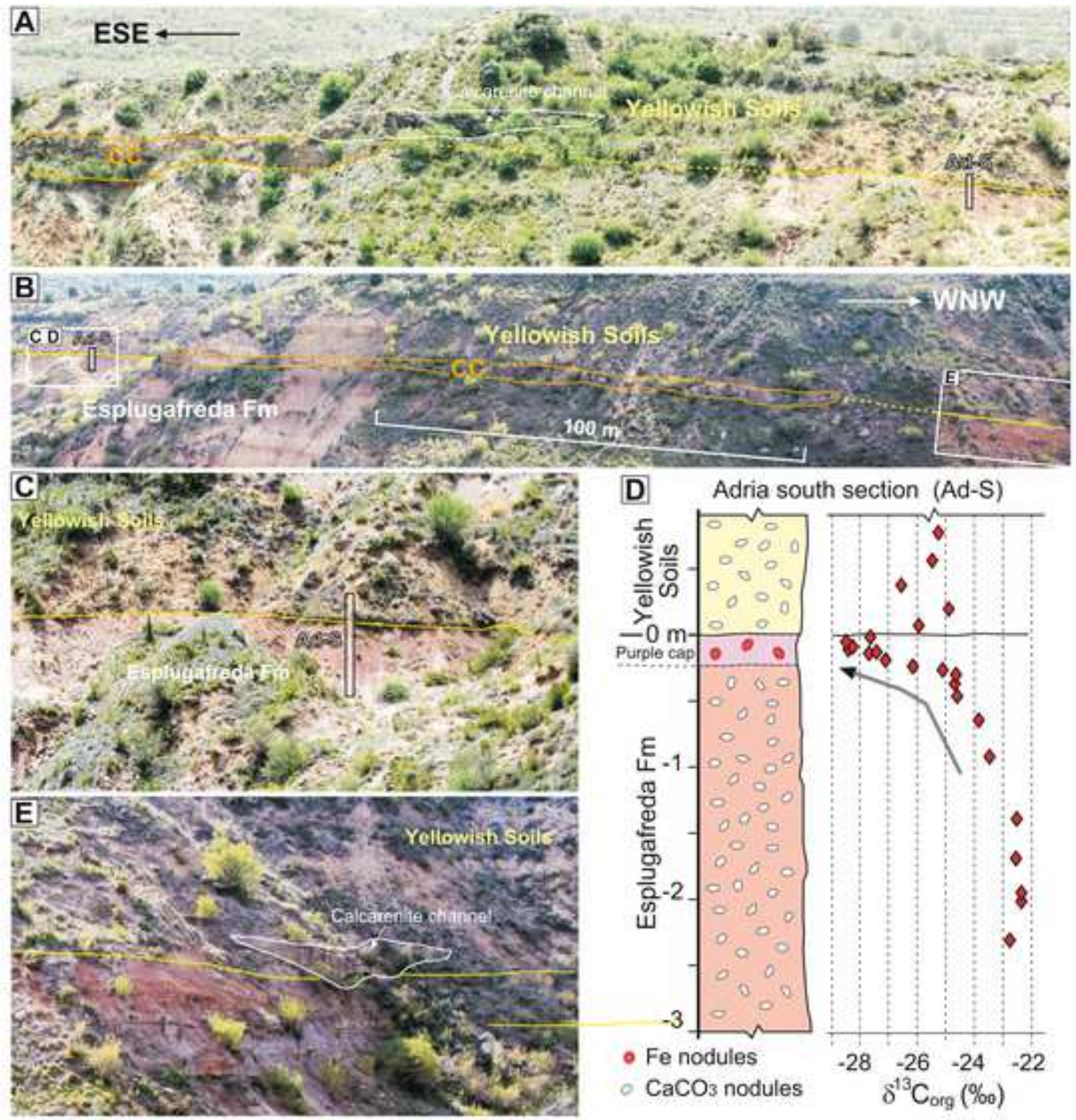

Pujalte et al Fig 10 

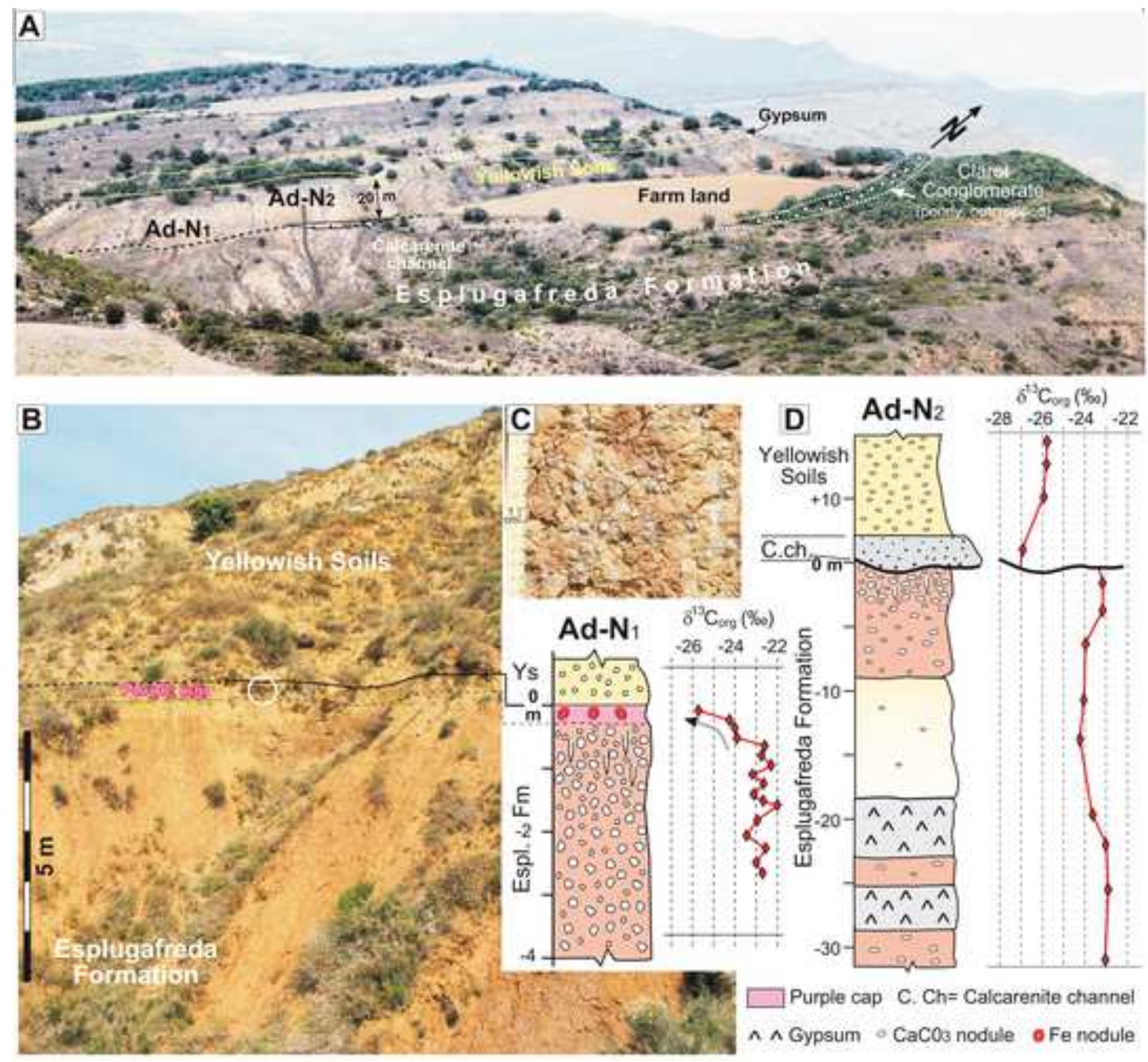

\section{Pujalte et al Fig 11}




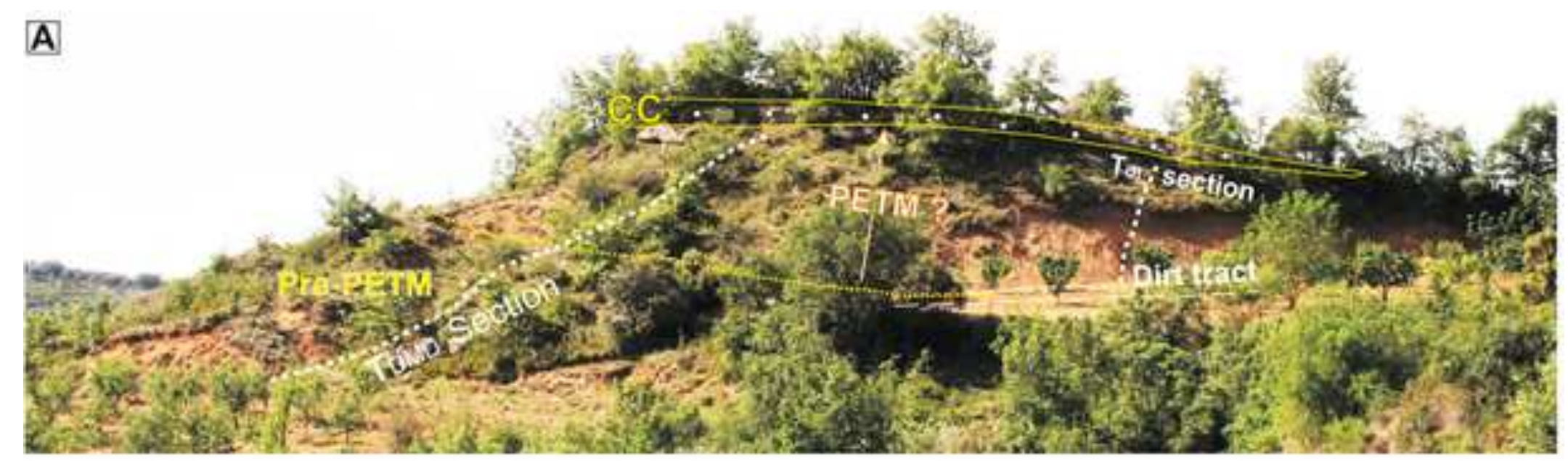

B Tomd Section

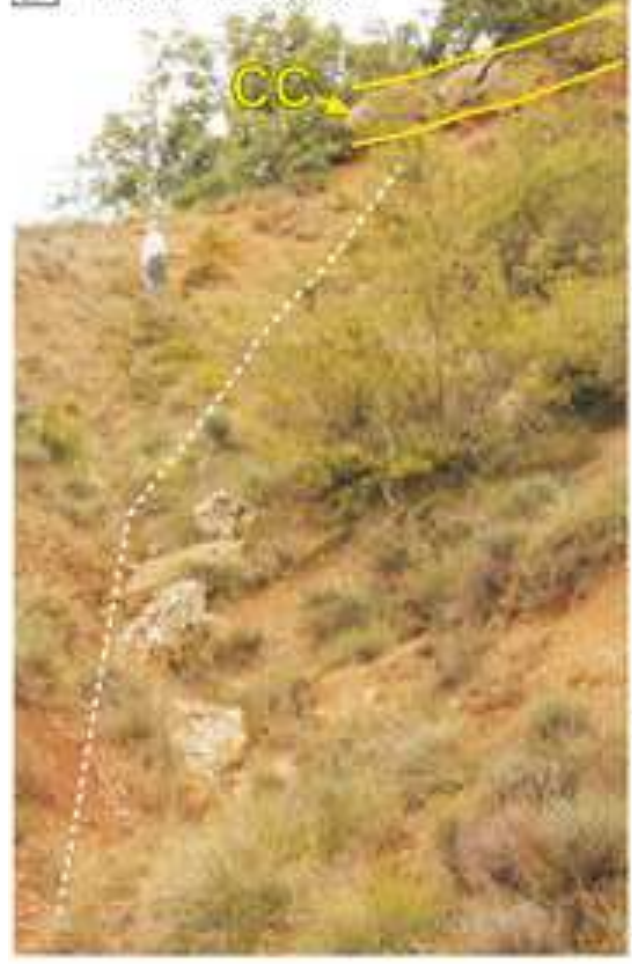

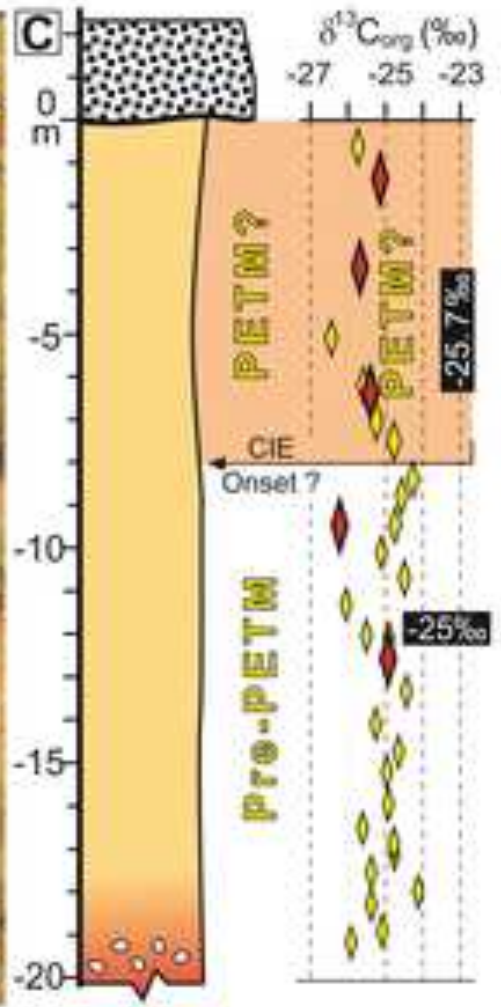

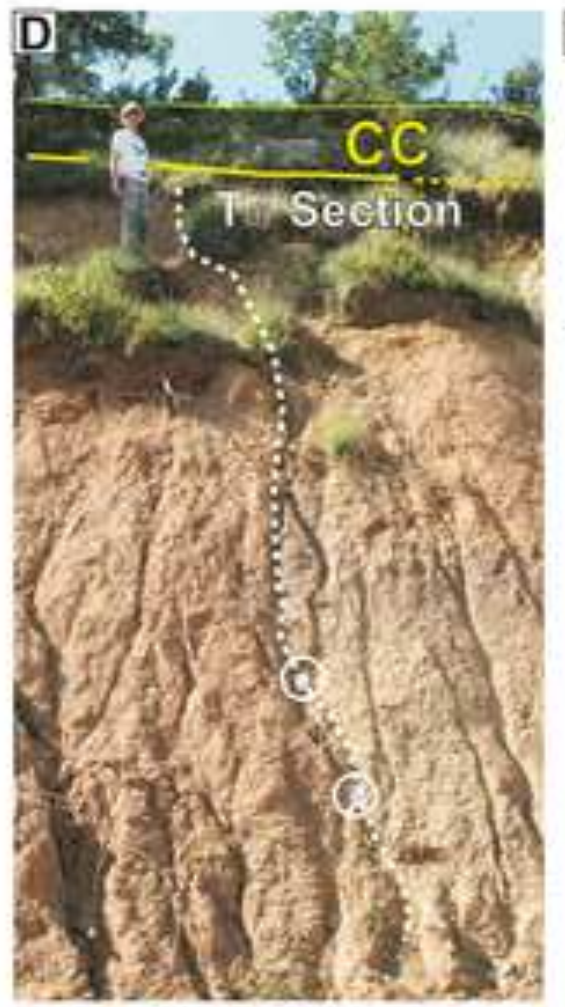

[E] $\delta^{12} \mathrm{C}_{\operatorname{cog}}(\%)$

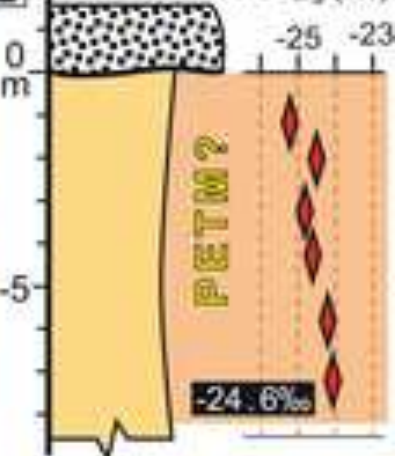

Isotopes

Average value

$\checkmark$ After DMD (09-19) This paper

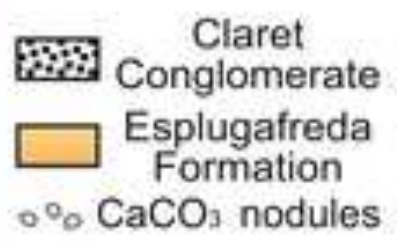

Pujalte et al - Fig 12 


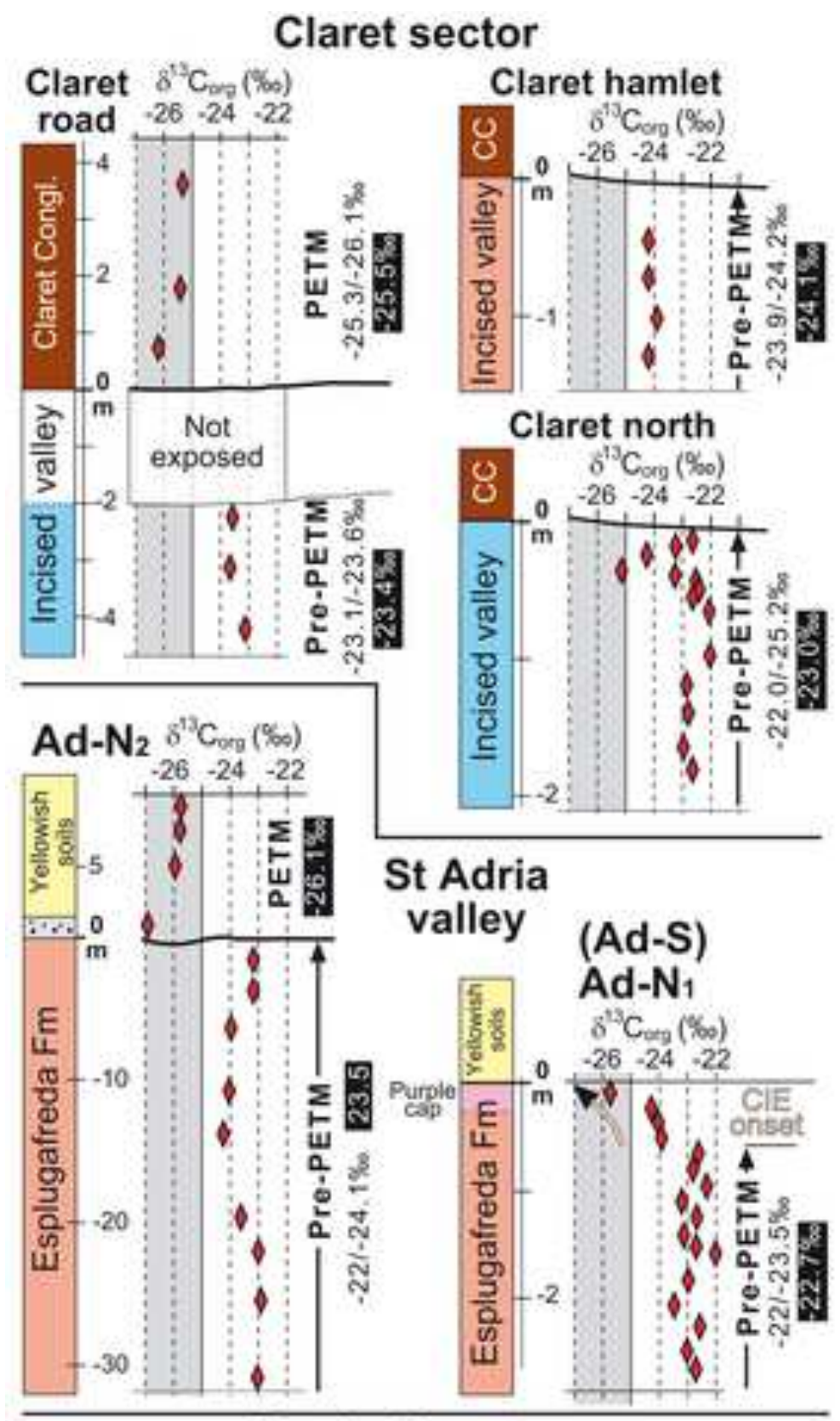

\section{Tendrui sector}
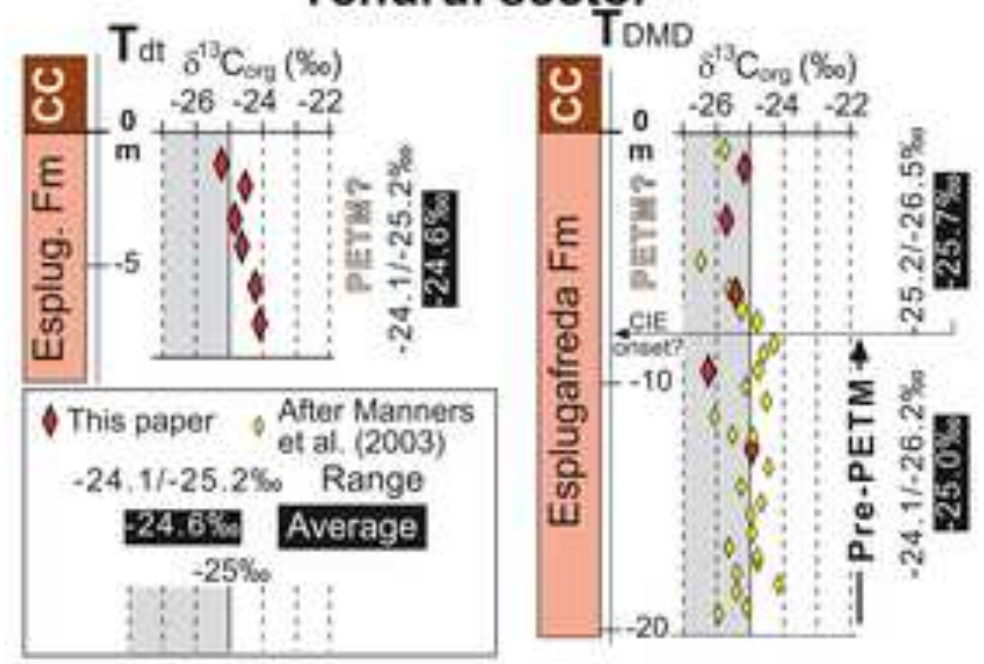


\section{Declaration of competing interest}

The authors declare that they have no known competing financial interests or personal relationships that could have influenced the research reported in this paper 